\title{
Financial development and innovation: Cross-country evidence ${ }^{*}$
}

\author{
Po-Hsuan Hsu \\ Faculty of Business and \\ Economics \\ University of Hong Kong \\ paulhsu@hku.hk
}

\author{
Xuan Tian \\ Kelley School of Business \\ Indiana University \\ tianx@indiana.edu
}

\author{
Yan Xu \\ College of Business \\ Administration \\ University of Rhode Island \\ yan_xu@mail.uri.edu
}

This version: February, 2013

\begin{abstract}
* We would like to thank an anonymous referee, Viral Acharya, Rui Albuquerque, Geert Bekaert, Utpal Bhattacharya, Matt Billett, Douglas Cumming, Joseph Fan, Harald Hau, Kai Li, Chen Lin, David Ng, Daniel Paravisini, Bill Schwert (the editor), Krishnamurthy Subramanian, Cong Wang, Yan Wang, Keith Wong, Tong Yu, conference participants at the 2011 China International Conference in Finance, the 2011 EFM Symposium, and the 2011 FMA Annual Meeting, as well as seminar participants at the University of Connecticut and Chinese University of Hong Kong for their valuable comments. Xuan Tian acknowledges financial support from Indiana University CIBER Faculty Research Grant. All errors remain our own.
\end{abstract}




\section{Financial development and innovation: Cross-country evidence}

We examine how financial market development affects technological innovation. Using a large data set that includes 32 developed and emerging countries and a fixed effects

identification strategy, we identify economic mechanisms through which the development of equity markets and credit markets affects technological innovation. We show that industries that are more dependent on external finance and that are more high-tech intensive exhibit a disproportionally higher innovation level in countries with better developed equity markets. However, the development of credit markets appears to discourage innovation in industries with these characteristics. Our paper provides new insights into the real effects of financial market development on the economy.

JEL classifications: G15; O30; R11

Keywords: financial development; innovation; external finance dependence; high-tech intensiveness 


\section{Introduction}

While innovation is vital to ensure a country's long-term economic growth and competitive advantage (Solow, 1957), motivating and nurturing innovation is very difficult. As Holmstrom (1989) points out, the whole innovation process is not only long, idiosyncratic, and unpredictable, but innovation also involves a very high probability of failure. Therefore, promoting innovation effectively requires well-functioning financial markets that play critical roles in reducing financing costs, allocating scarce resources, evaluating innovative projects, managing risk, and monitoring managers. Despite Schumpeter's (1911) argument that the development of financial markets is critical for a nation's innovation, rigorous empirical studies that link financial market development and technological innovation are sparse. Hence, the objective of this paper is to provide cross-country evidence for the real effects of financial market development on the economy from the perspective of technological innovation. Specifically, we examine the different impacts of equity market development and credit market development on innovation and identify economic mechanisms through which they occur.

A major challenge of our study is identifying the causal effects of financial market development on technological innovation, due to both reverse causality and omitted variable concerns. First, there is an old debate on the direction of causality between finance and growth. A large body of literature starting with Schumpeter (1911) argues that finance leads to economic growth, because the services that the financial sector provides allow capital and resources to be allocated to the highest value use with reduced risk of loss caused by adverse selection, moral hazard, or transaction costs. Conversely, a large body of literature follows Robinson (1952), who famously argues that "where enterprise leads, finance follows" (p. 86). This literature believes that economies with good growth opportunities develop financial markets to provide the funds necessary to support their good growth prospects. In such cases, the economy leads, and finance follows. Second, omitted variables may bias the estimation and statistical inferences that result from using traditional cross-country regressions. Unobservable industry or country characteristics related to both financial market development and innovation are left in the residual term of the regressions, which makes correct statistical inferences hard to draw.

Our identification strategy is to use a panel-based fixed effects identification approach that studies the specific economic mechanisms through which financial market development affects innovation, building on the seminal work of Rajan and Zingales (1998). Our panel-based 
approach captures both time-series and cross-sectional dynamics between financial markets and innovation, allowing for more reliable statistical inferences.

We examine two mechanisms motivated by economic theories about the functions of financial markets and institutions. First, we consider the most important function of financial markets: overcoming moral hazard and adverse selection problems and, therefore, reducing the firm's cost of external capital. Specifically, we examine whether industries that are more dependent on external finance innovate more in countries with more developed financial markets. Second, as high-tech industries usually undertake more innovative and risky projects that involve long and intensive research processes before final production, financial markets' function of evaluating long-term and risky projects and diversifying risk will crucially affect the financing of innovation. Hence, we study whether high-tech industries innovate more in countries with more developed financial markets when compared to those industries in countries with less developed financial markets.

When we examine these two economic mechanisms, we differentiate the effects of equity market development and credit market development on innovation. We propose that different effects of equity and credit markets may be due to the different payoff structures to equity and credit providers. We discuss these two mechanisms and related theories in more detail in Section 2; we also develop our testable hypotheses in this section.

We collect innovation and financial development data for 32 economies from the National Bureau of Economics Research (NBER) patent database, the Worldscope database, and the World Development Indicators and Global Development Finance (WDI/GDF) database. Our sample includes both developed countries such as the U.S., the U.K., and Japan, as well as emerging nations like Russia, India, and Brazil. Following Rajan and Zingales (1998), we assume that U.S. financial markets are relatively frictionless and informative, so we use U.S. data to form the benchmark measures of industry-level economic mechanisms.

Our baseline results show that industries that are more dependent on external finance and that are more high-tech intensive exhibit disproportionally higher innovation levels in countries with better developed equity markets. However, better developed credit markets appear to discourage innovation in industries with these characteristics. We conduct a number of robustness checks to examine whether our main results are robust to alternative econometric specifications (controlling for country-industry fixed effects and clustering standard errors only 
at the country level), alternative proxies for financial market development, alternative proxies for high-tech intensiveness, and alternative innovation proxies defined at the technology class level. Collectively, these tests help us understand where the variation that drives our main results originates.

Our paper offers new insights into the real effects of financial development and is related to two streams of literature. First, it contributes to the literature on finance and growth. Starting with Schumpeter (1911) and Robinson (1952), there has been a large literature trying to understand the relation between financial systems and economic growth. Recent theoretical work indicates two likely links between finance and growth: Bencivenga and Smith (1991) and Jappelli and Pagano (1993) argue that financial markets matter by affecting the volume of savings available to financial investments, while Greenwood and Jovanovic (1990) suggest that financial markets matter by increasing investment productivity. ${ }^{1}$ Second, our paper contributes to the emerging literature on finance and innovation that examines various strategies for promoting innovation. Manso (2011) argues that managerial contracts that tolerate failure in the short run and reward success in the long run are best suited for motivating innovation. Also, Ferreira, Manso, and Silva (2012) show that private rather than public ownership spurs innovation. Nanda and Rhodes-Kropf (2011) suggest that "hot" rather than "cold" financial markets help promote innovation. ${ }^{2}$ Unlike earlier studies, we use a rich cross-country data set to examine specific economic mechanisms through which finance affects innovation and document the contrasting impacts of equity market and credit market development.

Our paper is distinct from, but also complementary to, a few recent studies. Using a sample of U.S. IPO firms, Bernstein (2012) finds that going public significantly reduces firms' innovation quality. While this result is important, we believe this finding depends on the existence of a well-developed equity market in the U.S.; in other words, the negative effects of public equity markets on innovation along the intensive margin (i.e., U.S. firms only in his

\footnotetext{
${ }^{1}$ Empirical evidence linking finance and growth has shown that the size, depth, and liberalization of an economy's financial system positively affect its future growth in per capita, real income, entrepreneurship, employment, and output (e.g., King and Levine, 1993a; Jayarathe and Strahan, 1996; Rajan and Zingales, 1998; Beck and Levine, 2002; Black and Strahan, 2002; Bekaert, Harvey, and Lundblad, 2005).

${ }^{2}$ Empirical evidence shows that laws (Acharya and Subramanian, 2009; Acharya, Baghai, and Subramanian, 2012), stock liquidity (Fang, Tian, and Tice, 2011), investment cycles in financial markets (Nanda and Rhodes-Kropf, 2012), financial analysts (He and Tian, 2012), product market competition (Aghion, Bloom, Blundell, Griffith, and Howitt, 2005), investors' attitudes towards failure (Tian and Wang, 2011), and institutional ownership (Aghion, Van Reenen, and Zingales, 2013) all affect innovation.
} 
setting) would not exist to the same degree along the extensive margin in other countries with less developed equity markets. Meanwhile, Nanda and Nicolas (2011) show that bank distress during the Great Depression reduced both the quantity and quality of firm patenting, suggesting a positive role of credit markets in innovation. While they focus on U.S. markets during a special period, our study is based on a sample of 32 countries over a more recent 31 -year period. BravoBiosca (2007) uses a cross-sectional fixed effects identification approach in the period 19851994 and finds that both equity and credit markets increase innovation quantity, but that equity markets, rather than credit markets, are associated with more radical innovation. Different from his work, we adopt a panel-based fixed effects identification strategy and examine two distinct economic mechanisms through which the development of equity and credit markets affects innovation differently. Finally, Ayyagari, Demirgüç-Kunt, and Maksimovic (2011) use manager survey data from 47 emerging countries to show that more innovative firms are characterized by private ownership, highly educated managers, and access to external finance. Unlike the data used in this study, our data include both emerging and developed countries, and we examine the impacts of financial development on innovation at the aggregate level.

The rest of the paper is organized as follows. In Section 2, we discuss various economic theories and empirical findings to develop our testable hypotheses. In Section 3, we discuss our data collection and provide summary statistics. In Section 4, we describe our empirical strategy and report our test results. Finally, we conclude this paper in Section 5 and provide detailed discussions on variable definitions in the Appendix.

\section{Hypothesis development}

In this section, we develop testable hypotheses by discussing two economic mechanisms through which financial market development affects technological innovation, basing these hypotheses on economic theories and empirical findings. First, we examine whether financial market development is particularly beneficial to industries that are more dependent on external finance. Second, we study whether financial market development is particularly beneficial to industries that are more high-tech intensive. In discussing these two economic mechanisms, we emphasize the heterogeneous roles that equity markets and credit markets play. 


\subsection{Financial development, external finance dependence, and innovation}

The financial development literature suggests that the most important function of financial markets is to overcome adverse selection and moral hazard problems, thereby reducing a firm's cost of external capital. The seminal work of Rajan and Zingales (1998) shows that financial development promotes economic growth in sectors that are more dependent on external finance by providing lower financing cost to these sectors. However, equity markets and credit markets may play different roles in determining financing cost and, ultimately, influencing innovation.

Equity markets are more likely to have a positive effect on innovation in more external finance-dependent industries for three reasons. First, as Brown, Fazzari, and Petersen (2009) suggest, equity markets investors share in upside returns and there are no collateral requirements for equity financing; when additional equity is needed, equity financing would not increase a firm's probability of financial distress. Second, equity markets' function of producing information could be particularly useful when it comes to finance innovation. A well-known feature of equity markets is that, under rational expectations, investors are able to extract the relevant yet noisy information from equilibrium prices (Grossman, 1976). Thus, equity markets provide a mechanism that may make investors feel more comfortable in relinquishing control of their savings.

Third, equity markets facilitate the feedback effects of market security prices. Allen and Gale (1999) argue that innovative projects are usually difficult to evaluate, as information about their prospects is either sparse or hard to process, which often results in a wide range of opinions. Because equity markets provide timely equilibrium security prices, the development of equity markets allows valuable information about the prospects of firms' investment opportunities to affect firm managers' real investment decisions. Since industries that are highly dependent on external finance generally possess multiple innovative investment opportunities accompanied with sparse information, developed equity markets should fund innovative projects more and achieve more efficient resource allocation.

Credit markets, by contrast, are less likely to promote innovation in industries that are more dependent on external finance for two reasons. First, the feedback effects featured in noisy rational expectation equilibrium is absent in bank financing. Rajan and Zingales (2001) suggest that, due to a lack of price signals, banks might continue financing firms, even for projects with 
negative returns. Therefore, as Beck and Levine (2002) argue, bank-based financial systems could inhibit the efficient flow of external finance to the newest, most innovative endeavors. Second, innovative firms often have unstable and limited amounts of internally generated cash flows to service debt (Brown, Martinsson, and Petersen, 2012). Also, the knowledge assets that R\&D investment creates are usually intangible and partly embedded in human capital (Hall and Lerner, 2010). Thus, the limited collateral value of intangible assets largely restricts the use of debt (Brown, Fazzari, and Petersen, 2009), which explains why banks prefer to use physical assets instead of R\&D investment to secure loans.

These arguments suggest that equity issues rather than debt issues are likely the main marginal source of R\&D finance for firms that are dependent on external finance. The above discussion leads to our first hypothesis:

Hypothesis $1\left(\mathbf{H}_{\mathbf{1}}\right)$ : Equity market development will promote innovation in industries that are more dependent on external finance. Credit market development will discourage innovation in industries that are more dependent on external finance.

\subsection{Financial development, high-tech intensiveness, and innovation}

An important function of financial markets is to help market participants diversify their risk (King and Levine, 1993b), which is particularly important for nurturing technological innovation. High-tech companies usually are engaged in the design, development, and introduction of new products and/or innovative manufacturing processes through the systematic application of scientific and technical knowledge; due to this engagement, innovation with advanced and novel technological content is riskier and more idiosyncratic than routine tasks (Holmstrom, 1989). Hall and Lerner (2010) argue that such uncertainty can be extreme and would not be a simple matter of a well-specified distribution with a mean and variance. Therefore, industries that are more high-tech intensive are typically riskier than industries that are less prone to high technologies.

Equity markets could be particularly helpful to innovation in high-tech industries. First, equity markets provide a rich set of risk management tools, encouraging investors to shift their portfolios toward projects with higher risk but also higher expected returns, i.e., innovative projects (Levine, 2005; Bravo-Biosca, 2007). Second, existing literature shows that equity markets can offer higher stock prices to innovative firms and encourage innovation. For 
example, Kapadia (2006) finds that stock investors prefer the positive skewness in stock returns that are mostly provided by high-tech industries consisting of successful firms (e.g., Microsoft, Google). Also, Pástor and Veronesi (2009) argue that stocks related to new technologies characterized by high uncertainty and greater productivity are priced higher when stock investors learn more about their technologies.

Compared to equity markets, credit markets are less likely to promote innovation in hightech industries for two reasons. First, banks are excessively concerned with avoiding risky activities and failures. Therefore, their control could lead firms to under-invest in innovative projects with high uncertainty (Stiglitz, 1985). Many empirical studies support this argument: Berger and Udell (1990) find that risky firms typically have to pledge collateral to obtain debt finance, which is difficult for innovative industries characterized by not only high intangible asset (e.g., R\&D input, intellectual property) value, but also greater uncertainty; Weinstein and Yafeh (1998) find that banks, as major debt holders, are likely to be more risk averse than equity holders; and Nakatani (1984) suggests that firms with closer relationships with banks are less likely than other firms to engage in risky operations. Morck and Nakamura (1999) thus conclude that credit markets have an inherent bias toward conservative investments, which discourages firms from investing in innovative projects and encourages them to more willingly shut down ongoing innovative ones.

Second, credit markets may be less able to overcome information and agency problems in high-tech industries. Brown, Fazzari, and Petersen (2009) show that debt is a poor substitute for equity in financing high-tech firms, due to the adverse selection that results from the inherent riskiness of R\&D investment, as well as moral hazard issues, since high-tech firms can more easily substitute high-risk for low-risk projects. Hall and Lerner (2010) point out that technological investment is an intangible asset that is hard to measure, that is firm- or industryspecific, and that is costly to re-deploy. Moreover, technological investment is subject to agency problems to a greater extent when managers are also shareholders. The abovementioned information and agency problems are even more severe for high-tech industries. Therefore, banks and other debt holders would avoid providing funds to these high-tech firms for fear of managers' and equity holders' ex post overinvestment. In addition, banks could adversely affect innovation due to their own informational advantages. For example, Hellwig (1991) and Rajan (1992) find that powerful banks frequently stifle innovation by extracting rents through their 
information production. Collectively, these studies and our related discussion lead to our second hypothesis:

Hypothesis $2\left(\mathbf{H}_{2}\right)$ : Equity market development will promote innovation in high-tech industries. Credit market development will discourage innovation in high-tech industries.

\section{Data and summary statistics}

We begin our sample selection procedure by focusing on countries with a large number of U.S. patents, based on the record of the U.S. Patent and Trademark Office (USPTO) (available at http://www.uspto.gov/web/offices/ac/ido/oeip/taf/h_at.htm). Due to data limitation, we drop a few actively patenting economies in the list. First, Czechoslovakia is excluded from our sample, as it has been separated into the Czech Republic and the Slovak Republic since 1993. Next, we exclude China and Hong Kong, as they are not included in the Industrial Statistics Database of the 2008 edition of the United Nations Industrial Development Organization (UNIDO) database that we use later to construct control variables. Also, Taiwan is dropped because its relevant statistics are not available from the WDI/GDF database. After making these adjustments, we end up with a panel data set that includes 32 economies: Argentina, Australia, Austria, Belgium, Brazil, Canada, Denmark, Finland, France, Germany, Hungary, India, Ireland, Israel, Italy, Japan, Korea, Luxembourg, Malaysia, Mexico, Netherlands, New Zealand, Norway, Poland, Russia, Singapore, South Africa, Spain, Sweden, Switzerland, the U.K., and the U.S. This sample spans a wide range of countries that includes both developed and emerging economies.

\subsection{Innovation measures}

We construct five innovation measures. Our first innovation measure, Patent ${ }_{j, i, i}$, is the number of eventually granted patents ("patent counts") in two-digit SIC industry $j$ that are invented by individuals or non-government institutions from country $i$ in year $t$. This innovation measure captures the quantity of innovation output and is based on the updated NBER patent database that contains detailed information of all USPTO-approved patents in the period 19762006. ${ }^{3}$ Following the existing literature, we focus on the patents that are filed by individuals or non-government institutions in manufacturing industries with two-digit SIC codes between 20

\footnotetext{
${ }^{3}$ The updated NBER patent database is available at: https://sites.google.com/site/patentdataproject/Home. It consists of detailed patent and citation information, such as the patent application year, grant year, the nationality of patent inventors, the identity of patent assignees, three-digit technology classes, the number of citations received by each patent, and the Hall, Jaffe, and Trajtenberg (2005a) weighting factor.
} 
and 39, because patents are most valuable and crucial to manufacturing industries than other industries. We discuss our constructions of industrial patents in more detail in Appendix A.

A few issues about our innovation measure, Patent ${ }_{j, i, t}$, are worth discussing. First, using U.S. patent data to measure cross-country innovation performance has been widely adopted in previous studies (e.g., Griffith, Harrison, and Van Reenen, 2006; Acharya and Subramanian, 2009). Due to the territorial principle in U.S. patent laws, anyone intending to claim exclusive rights for inventions is required to file U.S. patents. Since the U.S. has been the largest technology consumption market in the world over the past few decades, we follow earlier studies by assuming that all important inventions from other countries have been patented in the U.S. Second, we exclude patents filed by governments because their patents are less likely driven by financial market development (Bravo-Biosca, 2007). Third, we calculate annual country-industry patent counts based on each patent's application year instead of its grant year, as the application year better captures the actual effective time of innovation (Griliches, Pakes, and Hall, 1987), and an invention starts to affect the real economy since its inception. Finally, we assign patents to countries by their inventors rather than assignees (i.e., owners) because we aim to better measure the intensity of innovative activities in each country. Doing so avoids a potential sampling bias because some gigantic firms own a large pool of patents due to outsourcing research activities overseas.

A reasonable concern for using patent counts as a proxy for innovation is that, despite their straightforward intuition and easy implementation, these counts do not help to distinguish groundbreaking inventions from incremental technological discoveries. Therefore, we consider patent citations, Citation ${ }_{j, i, t}$, as the second innovation measure, defined as the number of forward patents citing the patents in industry $j$ that are invented by individuals or non-government institutions from country $i$ in year $t$. As suggested in prior studies (e.g., Trajtenberg, 1990; Harhoff, Narin, Scherer, and Vopel, 1999; Aghion, Van Reenen, and Zingales, 2013), patent citations account for the influence of inventions and may better capture technological innovation quality and the innovation's market value. Since patents could keep receiving citations well beyond 2006 (the ending year of our sample), a simple count of patent citations is subject to the truncation bias. Therefore, we adjust the number of patent citations by using a weighting factor based on Hall, Jaffe, and Trajtenberg (2005a), who estimate the shape of the citation-lag distribution. 
While more patent citations are typically interpreted as having greater impact, the distribution of citations is also important. Therefore, we consider two more patent-based measures - patent originality and generality_following Hall, Jaffe, and Trajtenberg (2005a). Patents that cite a wider array of technology classes of patents are viewed as having greater originality, while patents being cited by a wider array of technology classes of patents are viewed as having greater generality. Both patent originality and generality reflect the fundamental importance of the innovation being patented.

Following the existing literature, we define a patent's originality score as one minus the Herfindahl index of the three-digit technology class distribution of all the patents it cites. The higher a patent's originality score, the more that the patent draws upon a more diverse array of existing knowledge. Meanwhile, we define a patent's generality score as one minus the Herfindahl index of the three-digit technology class distribution of all the patents that cite it. The higher a patent's generality score, the more that the patent is being drawn upon by a more diverse array of subsequent inventions. We then aggregate up individual patents' originality and generality scores to the industry level and compute Originality $_{j, i, t}^{*}$ and Generality $_{j, i, t}^{*}$ respectively, for industry $j$ in country $i$ in year $t$.

Our last innovation measure is the industry-level R\&D expenses. We use the Worldscope database that includes all public firms' annual R\&D expenses (WS item 01201) to construct the industry-level R\&D measure for each of the 32 countries. Specifically, we calculate each industry's annual R\&D expenses, $R \& D_{j, i, t}^{*}$, as the sum of the $\mathrm{R} \& \mathrm{D}$ expenses of all firms in industry $j$ in country $i$ in year $t$. A word of caution is that, while the R\&D measure is straightforward to interpret and $\mathrm{R} \& \mathrm{D}$ is an important innovation input, there is no complete industry-level data on non-U.S. R\&D expenses available to the best of our knowledge. Therefore, we resort to the Worldscope database, which has its own limitations. First, this database only covers publicly traded firms. Hence, our measure leaves out R\&D that privately held firms and individuals conduct. Second, there is a concern about the R\&D information reported in the Worldscope database, as many non-U.S. firms do not report or are not required to report R\&D expenses in their financial statements, due to different accounting standards across countries. However, a missing value of $R \& D$ does not necessarily mean that the firm is not engaging in innovative activities. Thus, we treat $R \& D_{j, i, t}^{*}$ as a supplementary industry-level innovation proxy and interpret its results with caution. 
Table 1 Panel A reports the summary statistics of our innovation measures across the 32 sample countries by averaging these measures over industry and year. Developed countries such as Japan, Germany, France, and the U.K. lead in all innovation proxies, while emerging economies such as Brazil, India, and Russia exhibit relatively lower levels of innovation. The U.S. leads in all innovation measures, largely because the innovation output measures are based on the U.S. patent system.

Table 1 Panel B reports the summary statistics of our innovation measures across the 20 sample industries by averaging these measures over country and year. Electronic and Other Electrical Equipment and Components (SIC 36), Industrial and Commercial Machinery and Computer Equipment (SIC 35), and Chemicals and Allied Products (SIC 28) are the three most productive industries in patent counts. They produce 1,228 patents, 1,166 patents, and 1,164 patents, respectively, in an average country per year. These industries also produce the most influential patents as they have the highest values in patent citations, originality, and generality. Meanwhile, Transportation Equipment (SIC 37), Electronic and Other Electrical Equipment and Components (SIC 36), and Chemicals and Allied Products (SIC 28) invest the most in R\&D (2.749, 2.502, and 2.391 million, respectively).

Following Rajan and Zingales (1998), we remove the U.S. from our testing sample to avoid a potential local bias problem, since we use patents filed in the U.S. to measure non-U.S. countries' technological output. Nevertheless, instead of dismissing U.S. patent data, we use them to control for different industries' propensity for patenting in the U.S. over time, or timevarying innovation opportunities. Specifically, assuming that the patenting propensity of U.S. firms in a given industry-year is a good benchmark, we scale industry $j$ 's patent counts in country $i$ in year $t$, Patent $_{j, i, t}^{*}$, by its corresponding value in U.S. data, Patent ${ }_{j, U S, t}$, and obtain each industry's relative patent counts Patent $_{j, i, t}\left(=\right.$ Patent $_{j, i, t}^{*} /$ Patent $_{j, U S, t}{ }^{*}$ ), which facilitates a cross-sectional comparison. This variable serves as our first main proxy for industry $j$ 's innovation in country $i$ in year $t$. We then use a similar approach to scale other innovation measures including Citation $_{j, i, t}^{*}$, Originality $_{j, i, t}^{*}$, Generality $_{j, i, t}^{*}$, and $R \& D_{j, i, t}^{*}$ by their corresponding industry-level values in U.S. data, including Citation ${ }_{j, U S, t}$, Originality $_{j, U S, t}{ }^{2}$ Generality $_{j, U S, t}^{*}$, and $R \& D_{j, U S, t}^{*}$ and obtain Citation $_{j, i, t}$, Originality $_{j, i, t}$, Generality $_{j, i, t}$, and $R \& D_{j, i, t}$, respectively, to measure industry $j$ 's relative innovation in country $i$ in year $t$. 
Panel $\mathrm{C}$ of Table 1 reports the summary statistics of innovation proxies in the pooled country-industry-year sample. The averages of Patent $_{j, i, t}$ Citation $_{j, i, t}$, Originality $_{j, i, t}$, Generality ${ }_{j, i, t}$, and $R \& D_{j, i, t}$ are $5.7 \%, 5.0 \%, 4.9 \%, 5.4 \%$, and $20.5 \%$, respectively. The statistics of patent-based proxies suggest that, for example, the number of patents generated by an industry in a non-U.S. country is, on average, about $5.7 \%$ of that produced by the same industry in the U.S. In addition, the R\&D investment made by all public firms in an industry in a non-U.S. country amounts to about one fifth of that made by all U.S. public firms.

\subsection{Financial development measures and control variables}

We collect annual financial market development data from the WDI/GDF database. In the existing literature, a country's overall financial development is measured by the ratio of stock market capitalization plus domestic credit to GDP (e.g., Rajan and Zingales, 1998). However, since our goal in this study is to understand how equity market development and credit market development differently affect a country's innovation, we construct two separate proxies for equity market and credit market development. Following earlier studies (e.g., Beck, Levine, and Loayza, 2000; Beck and Levine, 2002; Djankov, McLiesh, and Shleifer, 2007), our proxy for the equity market development of country $i$ in year $t$ is

$$
\text { Equity }_{i, t}=\text { Stock Market Capitalization }_{i, t} / G D P_{i, t} \text {, }
$$

i.e., the ratio of country $i$ 's stock market capitalization in year $t$ over its GDP in year $t$. Stock market capitalization is defined as the summation of share price times the number of shares outstanding of each listed stock. Following Rajan and Zingales (1998), our proxy for the credit market development of country $i$ in year $t$ is

$$
\text { Credit }_{i, t}=\text { Bank Credit }_{i, t} / G D P_{i, t} \text {, }
$$

i.e., the ratio of country $i$ 's domestic credit provided by the banking sector in year $t$ over its GDP in year $t .^{4}$

As reported in Panel A of Table 1, equity market development (Equity) and credit market development (Credit) vary across countries to a great extent. Excluding the U.S., equity market development ranges from 0.136 (Poland) to 1.774 (Switzerland), and credit market development

\footnotetext{
${ }^{4}$ Domestic credit provided by the banking sector is defined as all credit to various sectors on a gross basis, except to the central government, which is on a net basis. The banking sector includes monetary authorities, deposit money banks, and other banking institutions. We use this proxy as our primary proxy for credit market development and will use the ratio of all private credit to GDP later in the robustness check section, as the latter contains non-bank credit.
} 
ranges between 0.282 (Russia) and 2.548 (Japan). Panel C shows that Equity and Credit in the pooled sample have mean values of 0.767 and 0.951 with standard deviations of 0.711 and 0.511 , respectively. ${ }^{5}$

In our econometric framework that we discuss later, besides the main variables of interest, we only need to control for explanatory variables that vary with country, industry, and year, and affect innovation. We construct two such variables: the industrial share of total value added, and the industrial share of export to the U.S. We control for the industrial share of total value added, due to the heterogeneous degrees of development across different industries within one country, as suggested by Rajan and Zingales (1998) and Levine (2005). Specifically, we construct industry $j$ 's share of total value added in manufacturing industries in country $i$ in year $t$, Value-Added $_{j, i, t}$, using the Industrial Statistics Database of the United Nations Industrial Development Organization (UNIDO). We control for the industrial share of export to the U.S. because this share reflects each industry's propensity to export to the U.S., which may affect its intention to file patents in the U.S. for intellectual property protection, as suggested by BravoBiosca (2007). We also construct $U S$-Export ${ }_{j, i, t}$, as industry $j$ 's share of country $i$ 's total export to the U.S. in year $t$, using the United Nations Commodity Trade Statistics database. We provide the details of Value-Added and US-Export variable constructions in Appendix B. By including these two variables that change with country, industry, and year in our econometric framework, we mitigate a potential omitted variables bias arising from the structural change of a country's industries or international trade that affects both financial development and innovation.

Table 1 Panel A shows that Value-Added ranges from 4.5\% (India and Malaysia) to 12.3\% (New Zealand), and Panel B shows that Value-Added ranges from 11.8\% (Fabricated Metal Products, SIC 34, and Industrial and Commercial Machinery and Computer Equipment, SIC 35) to $0.5 \%$ (Tobacco Products, SIC 21). Panel C reports that the pooled mean and standard deviation of Value-Added are 5.0\% and 5.6\%, respectively. US-Export ranges from 4.3\% (India) to $5.1 \%$ (Luxembourg and Russia) country-wise, as reported in Panel A, and from 13.1\% (Industrial and Commercial Machinery and Computer Equipment, SIC 35) to $0.0 \%$ (Tobacco Products, SIC 21) industry-wise, as reported in Panel B. Finally, its pooled average (standard deviation) is $4.7 \%(6.3 \%)$, as reported in Panel C.

\footnotetext{
${ }^{5}$ Note that the financial development variables are constructed at the country-year level. Therefore, we do not report its statistics by industry in Panel B of Table 1, as they will be identical across industries.
} 


\subsection{Industry-level mechanism variables}

We construct two industry-level variables as proxies for economic mechanisms that we discussed in Section 2 to help us identify how financial market development affects innovation: dependence on external finance (Dependence) and high-tech intensiveness (High-tech). Following Rajan and Zingales (1998), we identify an industry's dependence on external finance and high-tech intensiveness from the data on U.S. public firms, assuming that financial markets in the U.S. are relatively frictionless and informative. Under the further assumption that industry characteristics based on U.S. firm data carry over to other countries, we use these characteristics to help us identify the effect of financial market development on innovation in a cross-country setting. Moreover, since we aim to explore how time-varying financial development affects innovation through various economic mechanisms measured by industrial characteristics, it is necessary for us to use time-invariant industrial characteristics in our sample period to prevent endogeneity driven by industrial factors.

To construct industry $j$ 's dependence on external finance (Dependence $e_{j}$ ), we first collect the year-end data of cash flows from operations, capital expenditures, and R\&D expenses of all public firms listed in three major U.S. stock exchanges (New York Stock Exchange, American Stock Exchange, and National Association of Securities Dealers Automated Quotations) from the Compustat database. Following Rajan and Zingales (1998), we define cash flows from operations as funds from operations (item 110) plus decreases in inventories (item 3), decreases in receivables (item 2), and increases in payables (item 70). Capital expenditures and R\&D expenses are items 128 and 46, respectively, from the Compustat database. We calculate each firm's dependence on external finance as capital expenditures plus R\&D expenses minus cash flows from operations, all divided by the sum of capital expenditures and R\&D expenses. Each industry's dependence on external finance is calculated as the median of all firms' dependence on external finance in a year. We then compute Dependence Das the time series median of industry $j$ 's dependence on external finance during the period 1976-2006. An industry with higher external finance dependence uses more external financing to fund its tangible and intangible investment.

High-tech firms typically use state-of-the-art techniques and have high R\&D investment. We thus first calculate each firm's high-tech intensiveness as the time-series median of its annual growth in R\&D expenses (item 46) during the period 1976-2006. Industry $j$ 's high-tech 
intensiveness $\left(\mathrm{High}\right.$ - $\left.\mathrm{Tech}_{j}\right)$ is calculated as the cross-sectional median of all firms' high-tech intensiveness in that industry. We assume, in the spirit of Rajan and Zingales (1998), that the R\&D growth of U.S. public firms appropriately captures the high-tech intensiveness of all industries due to the full and standardized disclosure of R\&D expenses that U.S. accounting standards have required (Financial Accounting Standards Board Statement No. 2) since 1975. In the robustness check section, we construct an alternative proxy of high-tech intensiveness that is based on financial markets' valuation of R\&D investment.

Panel B of Table 1 reports each industry's dependence on external finance and high-tech intensiveness. ${ }^{6}$ The value of external finance dependence ranges from 1.028 to 1.474 . For example, Apparel and Other Finished Products (SIC 23) and Transportation Equipment (SIC 37) are the most external finance dependent industries, while Chemicals and Allied Products (SIC 28) and Petroleum Refining and Related Industries (SIC 29) are the least external finance dependent industries. The high-tech intensiveness ranges from 0.975 to 1.188. Among them, Chemicals and Allied Products (SIC 28) and Apparel and Other Finished Products (SIC 23) industries are the top industries that have the highest high-tech intensiveness, while Printing, Publishing, and Allied Industries (SIC 27) and Petroleum Refining and Related Industries (SIC 29) have the lowest high-tech intensiveness. Panel $C$ of Table 1 reports the summary statistics across all country-industry-year observations of the mechanism variables. In our sample, an average industry has a mean value of dependence on external finance of 1.196 and high-tech intensiveness of 1.067. In addition, the standard deviations of external finance dependence and high-tech intensiveness are 0.102 and 0.047 , respectively.

\section{Empirical analysis and results}

In this section, we present our empirical tests and discuss the main findings. We describe our identification strategy in Section 4.1. In Sections 4.2 and 4.3, we examine how equity market and credit market development affect innovation through each of the two economic mechanisms proposed in Section 2. Finally, we conduct robustness checks in Section 4.4.

\footnotetext{
${ }^{6}$ Note that the industry-level mechanism variables are constructed based on U.S. data. Therefore, we do not report their summary statistics by country in Panel A of Table 1 because they are identical across countries.
} 


\subsection{Identification strategy}

As we discussed in our introduction, identifying the causal effects of financial market development on innovation is challenging. In a seminal work, Rajan and Zingales (1998) propose a fixed effects identification strategy that examines whether better-developed financial markets lead to higher economic growth in industries that are heavily dependent on external finance. Inspired by their work, we propose the following model that extends their framework from a cross-section to a panel-data structure. By estimating various forms of the model below, we examine the different effects of equity market and credit market development on innovation: ${ }^{7}$

$$
\begin{aligned}
\text { Innovation }_{j, i, t+1}= & \beta_{0}+\beta_{1}\left(\text { Equity }_{i, t} \times \text { Industry }_{j}\right)+\beta_{2}\left(\text { Credit }_{i, t} \times \text { Industry }_{j}\right) \\
& +\beta_{3} \text { Value-Added }_{j, i, t}+\beta_{4} \text { US-Export }_{j, i, t}+\eta_{i, t+1}+\mu_{j}+\varepsilon_{j, i, t+1},
\end{aligned}
$$

where Innovation $_{j, i, t+1}$ is one of our innovation proxies $\left(\right.$ Patent $_{j, i, t+1}$, Citation $_{j, i, t+1}$, Originality $_{j, i, t+1}$, Generality $_{j, i, t+l}$, and $\left.R \& D_{j, i, t}\right){ }^{8}$ Industry $_{j}$ is either Dependence or High-tech $_{j}$ that captures economic mechanisms and helps with identification. $\eta_{i, t+1}$ is the country-year fixed effect that absorbs time-varying country characteristics, such as the overall level of economic development, government policies, and country-wide reforms. $\mu_{j}$ is the industry fixed effect that absorbs the effects of industrial variation upon which our mechanism variables are constructed. One key advantage of our three-dimensional (country-industry-year) panel is that it allows us to use interacted fixed effects to control for a wide array of omitted variables. We cluster standard errors by country and industry. When we interpret the regression results, we focus on the signs and significance levels of $\beta_{1}$ and $\beta_{2}$. If they are positive (negative) and significant, it suggests that equity market development or credit market development exerts a disproportionately positive (negative) effect on industries that are highly dependent on external finance and that are more high-tech intensive.

In addition to examining the separate effects of equity market and credit market development on innovation, we study the effects of overall financial market development as well. Specifically, we combine equity and credit levels to construct an overall financial development measure and estimate the following model:

\footnotetext{
${ }^{7}$ We thank an anonymous referee for insightful comments leading to this framework. We believe that, given our long time-series, a panel estimation framework better describes the dynamics among financial institutions and innovative activities, and leads to more reliable statistical inferences.

${ }^{8}$ Following previous empirical studies that propose a contemporaneous relation between capital structure and R\&D (e.g., Aghion, Bond, Klemm, and Marinescu, 2004), we use a contemporaneous regression to study the effect of financial development on R\&D, such that all the terms in the regression are at year $t$.
} 


$$
\begin{aligned}
\text { Innovation }_{j, i, t+1}= & \delta_{0}+\delta_{1}\left(\text { Overall }_{i, t} \times \text { Industry }_{j}\right)+\delta_{2} \text { Value-Added }_{j, i, t}+\delta_{3} \text { US-Export }_{j, i, t} \\
& +\eta_{i, t+1}+\mu_{j}+\varepsilon_{j, i, t+1},
\end{aligned}
$$

where Overall $i, t$ measures overall financial development and is defined as the ratio of country $i$ 's stock market capitalization plus domestic credit provided by the banking sector in year $t$ over its GDP in year $t$. We again cluster standard errors by country and industry, and focus on the sign and significance of $\delta_{l}$ when we interpret the regression results.

\subsection{Dependence on external finance}

In this section, we examine how financial market development affects innovation through the first proposed economic mechanism: dependence on external finance. Table 2 reports the results from estimating Equations (3) and (4), using Dependence as the industry-level mechanism variable. The coefficient estimates of the interaction terms between Equity (Credit) and Dependence are identified from the cross-industry variation within a country, and they capture the differential effects of equity (credit) market development on innovation across industries. Intuitively, they report the difference in patenting among industries that are dependent on external finance to varying degrees with those that are in countries with varying degrees of equity (credit) market development.

We first estimate Equation (3) to understand the different effects of equity market and credit market development on innovation. We start with introducing key interaction variables individually. In the regressions with patent counts (Patent) serving as the innovation proxy, we find that the coefficient estimate of Equity $\times$ Dependence, $\beta_{1}$, is positive and significant at the $5 \%$ level when it is included alone in row (1). Also, the coefficient estimate of Credit $\times$ Dependence, $\beta_{2}$, is negative and significant at the $5 \%$ level when it is included alone in row (2). The preliminary findings appear to be consistent with $\mathbf{H}_{\mathbf{1}}$.

In row (3), we introduce both variables and find that the coefficient estimates of $\beta_{1}$ and $\beta_{2}$ are $0.047(p$-value $=0.008)$ and $-0.128(p$-value $=0.039)$, respectively. Based on the magnitudes of the coefficient estimates of $\beta_{1}$ and $\beta_{2}$ reported in row (3), patent counts for an industry with an average external finance dependence $(1.196)$ increase by $4.2 \%(=0.047 \times 1.196 \times 0.749)$ in a country with equity market development at the $75^{\text {th }}$ percentile (1.048) compared to a country with equity market development at the $25^{\text {th }}$ percentile (0.299); conversely, these patent counts decrease by $9.9 \%(=-0.128 \times 1.196 \times 0.645)$ in a country with credit market development at the 
$75^{\text {th }}$ percentile (1.195) compared to a country with credit market development at the $25^{\text {th }}$ percentile (0.550). These two numbers are economically large, given that the sample average of patent counts is $5.7 \%$. The results, based on the quantity of innovation output, are consistent with $\mathbf{H}_{1}$.

In row (4), we estimate Equation (4) in which the effect of a country's overall financial market development on innovation is examined. We find an insignificant coefficient estimate of $\delta_{1}$, possibly because equity markets and credit markets have opposite effects on patent counts, and their effects are attenuated when they are pooled together to examine the real effect of overall financial development. ${ }^{9}$

In the next four rows, we use patent citations (Citation) as the dependent variable to examine the effects of financial market development on innovation quality. The coefficient estimates of $\beta_{1}$ and $\beta_{2}$ are 0.012 and -0.077 (both are significant at the $5 \%$ level), respectively, when they are individually included in the regressions in rows (5) and (6). In row (7), we include both variables and find that the coefficient estimate of $\beta_{1}$ is 0.033 and significant at the $1 \%$ level, while that of $\beta_{2}$ is -0.087 and significant at the $5 \%$ level, respectively. The findings in row (7) suggest that citations for an industry with an average external finance dependence increase by $3.0 \%(=0.033 \times 1.196 \times 0.749)$ in a country with equity market development at the $75^{\text {th }}$ percentile compared to a country at the $25^{\text {th }}$ percentile; conversely, these citations decrease by $6.7 \%(=-0.087 \times 1.196 \times 0.645)$ in a country with credit market development at the $75^{\text {th }}$ percentile compared to a country at the $25^{\text {th }}$ percentile. The results are economically significant, given the sample average of patent citations of $5.0 \%$. In row (8), the coefficient estimate of $\delta_{1}$ is negative but insignificant, suggesting that a country's overall financial development does not appear to affect patent citations through the industry's dependence on external finance, which can likely be attributed to the opposite effects of equity market and credit market development on patent citations.

We then proceed to examine how financial market development affects the fundamental importance of the innovation being patented. We first examine patent originality (Originality) and find that the coefficient estimates of $\beta_{1}$ and $\beta_{2}$ are 0.011 ( $p$-values $\left.=0.016\right)$ and $-0.051(p$ values $=0.052$ ), respectively, when the key interaction variables are individually included in the

\footnotetext{
${ }^{9}$ This test also suggests that it is important to study the effects of equity markets and credit markets on innovation separately, as one may draw biased inferences when these two markets are pooled together.
} 
regressions in rows (9) and (10). In row (11), we include both Equity $\times$ Dependence and Credit $\times$ Dependence. The coefficient estimate of $\beta_{1}$ is 0.026 and significant at the $1 \%$ level, and that of $\beta_{2}$ is -0.059 and significant at the $5 \%$ level. The evidence suggests that patent originality for an industry with an average external finance dependence increases by $2.3 \%(=0.026 \times 1.196 \times$ 0.749 ) in a country with equity market development at the $75^{\text {th }}$ percentile compared to a country at the $25^{\text {th }}$ percentile, and decreases by $4.6 \%(=-0.059 \times 1.196 \times 0.645)$ in a country with credit market development at the $75^{\text {th }}$ percentile compared to a country at the $25^{\text {th }}$ percentile. These economic magnitudes are large, as the sample average of patent originality is $4.9 \%$. In row (12), the overall financial development does not appear to affect patent originality through an industry's dependence on external finance.

Next, we study patent generality (Generality). In row (15), when both interaction variables are included, the coefficient estimate of $\beta_{1}$ is 0.025 and significant at the $5 \%$ level. For an industry with an average external finance development, patent generality is $2.2 \%(=0.025 \times$ $1.196 \times 0.749)$ higher in a country with equity market development at the $75^{\text {th }}$ percentile compared to a country with equity market development at the $25^{\text {th }}$ percentile. Relative to the sample average of patent generality (5.4\%), the effect is economically significant. The coefficient estimate of $\beta_{2}$ is negative but statistically insignificant (it is insignificant also in row (14) in which Credit $\times$ Dependence is included alone), suggesting that credit market development does not affect patent generality through an industry's dependence on external finance. With respect to the effect of overall financial markets, we do not observe a statistically significant coefficient estimate of $\delta_{1}$.

Lastly, we use $\mathrm{R} \& \mathrm{D}(R \& D)$ as the innovation proxy. In rows (17) to (20), none of the coefficient estimates of $\beta_{1}$ and $\beta_{2}$ is statistically significant. This finding suggests that equity market and credit market development do not appear to affect R\&D in industries that are more dependent on external finance. Another possibility for the insignificant results is the low power of the tests caused by the substantially smaller R\&D sample, due to several R\&D data limitation issues for non-U.S. countries discussed in Section 3.1.

Overall, the results presented in this section support $\mathbf{H}_{\mathbf{1}}$. We show evidence that equity market development promotes innovation in industries that are more dependent on external finance, and that credit market development discourages innovation in these industries. 


\subsection{High-tech intensiveness}

In this section, we examine how financial development affects innovation through the second proposed economic mechanism: an industry's high-tech intensiveness. Table 3 reports the results using High-tech as the industry-level mechanism variable that reflects an industry's hightech intensiveness and serves as an instrumental variable for our analyses. We test $\mathbf{H}_{2}$, which states that equity market development promotes innovation in high-tech industries, while credit market development discourages innovation in high-tech industries.

We first estimate Equation (3) to understand the different effects of equity market and credit market development on innovation. In the regressions with patent counts as the innovation proxy, the coefficient estimate of $\beta_{1}$ is positive and significant at the $1 \%$ level when Equity $\times$ High-tech is included alone in row (1), and the coefficient estimate of $\beta_{2}$ is negative and significant at the $1 \%$ level when Credit $\times$ High-tech is included alone in row (2). In row (3), we include both variables and continue to observe a positive and significant coefficient estimate of $\beta_{1}(0.038$ with a $p$-value $<0.001)$ and a negative and significant coefficient estimate of $\beta_{2}(-0.096$ with a $p$-value $<0.001)$. Based on the magnitudes of the coefficient estimates reported in row (3), patent counts for an industry with an average high-tech intensiveness (1.067) increase by $3.0 \%(=0.038 \times 1.067 \times 0.749)$ in a country with equity market development at the $75^{\text {th }}$ percentile compared to a country with equity market development at the $25^{\text {th }}$ percentile; conversely, these counts decrease by $6.6 \%(=-0.096 \times 1.067 \times 0.645)$ in a country with credit market development at the $75^{\text {th }}$ percentile compared to a country with credit market development at the $25^{\text {th }}$ percentile. The economic significance is large, given that the sample average of patent counts is $5.7 \%$. Our evidence so far is consistent with $\mathbf{H}_{2}$.

In row (4), we estimate Equation (4) and examine the effect of a country's overall financial market development on innovation. We find a negative and significant coefficient estimate of $\delta_{1}$, which appears to be driven by the strong negative effect of credit market development on patent counts in high-tech industries.

Using patent citations as the dependent variable provides similar results. As shown in row (5), the coefficient estimate of $\beta_{l}$ is positive and significant at the $1 \%$ level when Equity $\times$ Hightech is included alone in the regression. The coefficient estimate of $\beta_{2}$ is negative and significant at the $1 \%$ level when Credit $\times$ High-tech is included alone in the regression in row (6). The coefficient estimate of $\beta_{1}$ is 0.030 and that of $\beta_{2}$ is -0.063 (both are significant at the $1 \%$ level) 
when both Equity $\times$ High-tech and Credit $\times$ High-tech are jointly included in the regression in row (7). The economic significance is large: patent citations for an industry with an average high-tech intensiveness increase by $2.4 \%(=0.030 \times 1.067 \times 0.749)$ in a country with equity market development at the $75^{\text {th }}$ percentile compared to a country with equity market development at the $25^{\text {th }}$ percentile, and decrease by $4.3 \%(=-0.063 \times 1.067 \times 0.645)$ in a country with credit market development at the $75^{\text {th }}$ percentile compared to a country with credit market development at the $25^{\text {th }}$ percentile. These changes are economically substantial, given that the sample average of patent citations is $5.0 \%$. In row (8), the coefficient estimate of $\delta_{I}$ is negative and significant, consistent with row (4).

We then proceed to study how financial market development affects the fundamental importance of the innovation being patented. We first examine patent originality. In rows (9) and (10), we include Equity $\times$ High-tech and Credit $\times$ High-tech in the regression individually. The coefficient estimate of $\beta_{1}$ is positive and significant at the $1 \%$ level and that of $\beta_{2}$ is negative and significant at the $10 \%$ level, respectively. In row (11), we include both key variables of interest in the regression and find that the coefficient estimate of $\beta_{1}$ is positive $(0.018$ with a $p$-value $<$ $0.001)$ and the coefficient estimate of $\beta_{2}$ is negative $(-0.026$ with a $p$-value $=0.043)$. With respect to economic magnitude, patent originality for an industry with an average high-tech intensiveness increases by $1.4 \%(=0.018 \times 1.067 \times 0.749)$ in a country with equity market development at the $75^{\text {th }}$ percentile compared to a country with equity market development at the $25^{\text {th }}$ percentile; conversely, originality decreases by $1.8 \%(=-0.026 \times 1.067 \times 0.645)$ in a country with credit market development at the $75^{\text {th }}$ percentile compared to a country with credit market development at the $25^{\text {th }}$ percentile. These two numbers are economically large, as the sample average of patent originality is $4.9 \%$. These findings further support $\mathbf{H}_{2}$. In row (12), we find that the overall financial development does not affect patent originality in high-tech intensive industries.

Next, we study patent generality. In row (15), when both equity market development and credit market development are included in the regression, the coefficient estimate of $\beta_{1}$ is 0.028 and that of $\beta_{2}$ is -0.067 , and both coefficients are significant at the $1 \%$ level. Patent generality for an industry with an average high-tech intensiveness increases by $2.2 \%(=0.028 \times 1.067 \times 0.749)$ in a country with equity market development at the $75^{\text {th }}$ percentile compared to a country with equity market development at the $25^{\text {th }}$ percentile, and decreases by $4.6 \%(=-0.067 \times 1.067 \times$ 
0.645 ) in a country with credit market development at the $75^{\text {th }}$ percentile compared to a country with credit market development at the $25^{\text {th }}$ percentile.

Lastly, we use R\&D as the innovation proxy in rows (17) - (20). The coefficient estimates of $\beta_{1}$ are positive and significant at the 5\% level across various specifications, while those of $\beta_{2}$ are negative but insignificant. These findings suggest that credit market development does not appear to affect $R \& D$, consistent with the results based on $R \& D$ reported in Table 2 .

Overall, we find that equity market development encourages innovation in high-tech industries, and that credit market development discourages innovation in high-tech industries. Our empirical evidence thus supports $\mathbf{H}_{2}$.

\subsection{Robustness checks}

In this section, we check the robustness of our main findings. We first examine whether the documented effects of equity market development and credit market development on innovation are robust to alternative specifications of the main model: specifically, whether the results are robust to controlling for country-industry fixed effects and to clustering standard errors only at the country level. Next, we study whether our main results are robust to alternative proxies for financial market development, an alternative proxy for an industry's high-tech intensiveness, as well as alternative proxies for innovation variables. For brevity, we only report the test results of Equation (3) when both equity market development and credit market development are included in the regression; nevertheless, we obtain qualitatively consistent findings when equity market development, credit market development, and overall financial development are each included separately in the regression. ${ }^{10}$

\subsubsection{Country-industry fixed effects}

Our main empirical set-up specified in Equation (3) controls for country-year fixed effects but not country-industry fixed effects because the main purpose of our study is to use industry-level mechanism variables as instruments to identify the causal effects of financial market development on technological innovation. However, one concern is that, instead of being affected by the financial development of each country, innovation is driven by unobservable but persistent industry-specific heterogeneity within each country. Such a concern can be alleviated

\footnotetext{
${ }^{10}$ These results are available for interested readers upon request.
} 
by explicitly controlling for country-industry fixed effects in our model. Specifically, we estimate the following model for this robustness check:

$$
\begin{aligned}
\text { Innovation }_{j, i, t+1}= & \beta_{0}+\beta_{1}\left(\text { Equity }_{i, t} \times \text { Industry }_{j}\right)+\beta_{2}\left(\text { Credit }_{i, t} \times \text { Industry }_{j}\right) \\
& +\beta_{3} \text { Value-Added }_{j, i, t}+\beta_{4} \text { US-Export } \\
j, i, t & +\eta_{j, i}+\varepsilon_{j, i, t+1},
\end{aligned}
$$

where $\eta_{j, i}$ denotes the dummies for industry $j$ in country $i$.

Panel A of Table 4 reports the estimation results when we use an industry's external finance dependence as the mechanism variable. In the first four regressions in which patentbased innovation proxies are the dependent variable, the coefficient estimates of $\beta_{1}$ are all positive and significant at the $1 \%$ level and those of $\beta_{2}$ are all negative and significant at the $1 \%$ level. We observe statistically significant estimates of $\beta_{1}$ and $\beta_{2}$ in the $\mathrm{R} \& \mathrm{D}$ regression as well. In Panel B, in which an industry's high-tech intensiveness is the mechanism variable, we continue to observe positive coefficient estimates of $\beta_{1}$ that are significant at the $1 \%$ level and negative coefficient estimates of $\beta_{2}$ that are significant at the $1 \%$ level in regressions when patent-based innovation proxies are the dependent variable. The result on R\&D is insignificant.

Overall, the significant effects of financial market development on innovation remain after controlling for country-industry fixed effects, suggesting that the effects of financial development on innovation through the two identified economic mechanisms are prevalent in all industries across all countries, rather than being specific to some industries in a particular country.

\subsubsection{Clustering standard errors by country}

In the main analysis, we cluster standard errors along two dimensions by both country and industry. When residual correlation in both dimensions is present, a two-way clustered standard error is well known to be a robust estimator and contains less bias (Petersen, 2009; Thompson, 2011). However, such bias reduction may be accompanied by higher variance of the estimates, potentially casting doubts on our reported statistical inference. To address this concern, we check whether our main results are robust to clustering standard errors only by country and report these results in Table 5 .

In Panel A, in which the economic mechanism is an industry's dependence on external finance, the coefficient estimates of $\beta_{1}$ remain positive and significant at the $5 \%$ level and those of $\beta_{2}$ remain negative and significant at the $1 \%$ or $5 \%$ level in the first four regressions in which 
patent-based innovation proxies are the dependent variable. The coefficient estimates of $\beta_{1}$ and $\beta_{2}$ become significant when $R \& D$ is the dependent variable if we cluster standard errors only by country. Panel B reports the robustness check results with an industry's high-tech intensiveness as the economic mechanism variable. The coefficient estimates of $\beta_{1}$ and $\beta_{2}$ remain statistically significant for patent-based innovation proxies. In conclusion, our main results are robust to clustering standard errors only by country.

\subsubsection{Alternative proxies for financial development}

As the current literature suggests different measures of financial development (see, for example, Levine, 2005), we follow Rajan and Zingales (1998) in choosing our empirical proxies for equity market and credit market development. In this subsection, we examine whether our main findings are robust to alternative financial development measures. To do so, we construct the ratio of stock market traded value to GDP as an alternative proxy for equity market development and construct the ratio of all private credit to GDP as an alternative proxy for credit market development. ${ }^{11}$ We report the results using alternative proxies for financial market development in Table 6.

In Panel A, we examine the mechanism of an industry's external finance dependence. In the regressions with patent-based innovation proxies as the dependent variable, the coefficient estimates of $\beta_{1}$ are positive and significant for Patent and Citation; the coefficient estimates of $\beta_{2}$ are all negative and significant. Once again, we do not find that financial development affects R\&D through an industry's dependence on external finance. In Panel B, we examine an industry's high-tech intensiveness, and we find positive and significant coefficient estimates for $\beta_{1}$ and negative and significant coefficient estimates for $\beta_{2}$ for all patent-based innovation proxies, except for Originality and $R \& D$.

When comparing these results with our main findings reported in Tables 2 and 3, we observe slightly weaker results based on alternative proxies of equity market and credit market development. One possible reason is that these alternative proxies have their own limitations and, therefore, could be less powerful than our main proxies. For example, Levine and Zervos (1998) point out that stock market traded value may contain a market expectation of future

\footnotetext{
${ }^{11}$ Both the ratio of stock market traded value to GDP and the ratio of all private credit to GDP are collected from the WDI/GDF database. Private credit is defined as financial resources (e.g., loans, purchases of non-equity securities, trade credit) provided to the private sector, as well as other accounts receivable that establish a claim for repayment.
} 
growth, which results in a spurious correlation between equity market development and economic growth. In addition, banks play a dominating role in credit markets and are powerful than other creditors; therefore, using private credit that includes the funding from all creditors to measure credit market development may underestimate the effects of credit markets on innovation.

\subsubsection{An alternative proxy for high-tech intensiveness}

We identify two economic mechanisms that help us identify the causal effect of financial market development on technological innovation. Our proxy for the first mechanism, an industry's dependence on external finance, is a well-received, standard proxy that has been used in many studies (e.g., Rajan and Zingals, 1998; Beck and Levine, 2002). However, our proxy for the second mechanism, an industry's high-tech intensiveness, is not as standard as our first proxy because the existing literature has developed a few different proxies to capture an industry's high-tech intensiveness. To ensure that our main results are not entirely driven by our proxy choice for an industry's high-tech intensiveness, we construct an alternative proxy that makes use of a financial market's valuation to R\&D investment.

Following Griliches (1981), Hall, Jaffe, and Trajtenberg (2005b), and Hall, Thoma, and Torrisi (2007), we construct an alternative proxy that captures industry $j$ 's high-tech intensiveness. ${ }^{12}$ Specifically, we calculate each industry's high-tech intensiveness for every year in two steps. First, we regress each firm's logarithmic ratio of market value (item 24 times item 25 ) to total assets (item 6) on R\&D expenses over the most recent five years (year $t-4$ to year $t$ ) scaled by total assets for each year, using all firms in each industry, and label the coefficient estimate as the industry's high-tech intensiveness in that year. We then compute High-tech ${ }_{j}$ as the time series median of industry $j$ 's high-tech intensiveness for the period 1976-2006.

We report the results with the alternative proxy for an industry's high-tech intensiveness in Table 7. We continue to observe positive and significant coefficient estimates of $\beta_{1}$ and negative and significant coefficient estimates of $\beta_{2}$ when patent-based innovation proxies are the dependent variable, although statistical significance levels are a bit lower compared to the main results reported in Table 3. Overall, our main findings are robust to the alternative proxy for an industry's high-tech intensiveness.

\footnotetext{
${ }^{12}$ We provide our underlying economic rationale, as well as detailed derivations for this alternative high-tech intensiveness measure, in Appendix C.
} 


\subsubsection{Innovation variables at the technology class level}

While our main tests are based on two-digit SIC industry-level innovation variables following Rajan and Zingales (1998) and Bravo-Biosca (2007), it is important to check the robustness of our results using innovation variables defined at the three-digit technology class level, a standard patent classification system based on the nature of patents assigned by the USPTO. Following Acharya and Subramanian (2009) and Acharya, Baghai, and Subramanian (2012), we first aggregate patent counts, citations, originality scores, and generality scores for 428 unique three-digit technology classes in each of 32 economies. We then scale each technology class $j$ 's patent counts, citations, originality scores, and generality scores in country $i$ for year $t$ by its corresponding value in U.S. data. Because R\&D data are not reported in technology classes (recall that it is not based on patent information obtained from the USPTO), we use the mapping approach described in Appendix A to convert R\&D from two-digit SIC codes to three-digit technology classes. In addition, we also convert industry-level mechanism variables and control variables from two-digit SIC codes to three-digit technology classes. We then estimate Equation (3) in which Innovation $_{j, i, t+1}$ is one of our innovation proxies in technology class $j$ in country $i$ for year $t+1$, Industry now refers to technology class $j$ 's external finance dependence or high-tech intensiveness, and $\mu_{j}$ now refers to the technology class fixed effect.

Table 8 presents our robustness test results using innovation variables defined at the three-digit technology class level. ${ }^{13}$ Panel A shows the test results with an industry's dependence on external finance as the mechanism variable. In the first four regressions in which patent-based innovation proxies are the dependent variable, the coefficient estimates of $\beta_{l}$ are all positive and statistically significant (except for Generality) and those of $\beta_{2}$ are all negative and significant. Panel B reports the robustness test results with an industry's high-tech intensiveness being the mechanism variable. The coefficient estimates of $\beta_{1}$ are generally positive and statistically significant (except for Generality), and those of $\beta_{2}$ are negative and significant in all regressions. Overall, we find that our main results are robust to alternative innovation proxies defined at the technology class level.

\footnotetext{
${ }^{13}$ Note that the number of observations increases in this table relative to previous tables because innovation, as well as other variables, are defined at the three-digit technology class level (there are 428 three-digit technology classes) instead of the two-digit SIC industry level (there are 20 two-digit SIC industries in our earlier analyses).
} 


\section{Conclusion}

This paper presents cross-country evidence on how the development of equity markets and credit markets affects technological innovation in different ways. Using a large data set that includes 32 developed and emerging countries between 1976 and 2006 and a fixed effects identification strategy, we identify economic mechanisms through which the development of equity markets and credit markets affects innovation. We show that industries that are more dependent on external finance and that are more high-tech intensive exhibit a disproportionally higher innovation level in countries with better developed equity markets. However, the development of credit markets appears to discourage innovation in industries that are more dependent on external finance and that are more high-tech intensive. We conduct a number of robustness checks and show that our main results are robust to alternative model specifications and alternative proxies for innovation, financial market development, and economic mechanism variables. Our study offers new insight to the real effects of financial market development on the economy. 


\section{Appendix A. Mapping USPTO technology class to SIC concordance}

It is a non-trivial task to assign U.S. patents to corresponding SIC industry codes because the USPTO does not require patent applicants and examiners to provide associated SIC codes in patent documents. Instead, the USPTO adopts a three-digit class system that assigns patents to three-digit technology classes that are based on technology categorization instead of finalproduct categorization. ${ }^{14}$ This feature of the USPTO data motivates several researchers to establish concordance lists to map patents to the SIC codes (Schmookler, 1966; Kortum and Putnam, 1997; Silverman, 2002). However, all these studies suffer from outdated data. Although the Office of Technology Assessment and Forecasting (OTAF) of the USPTO provides a concordance between the technology classes and the 1972 SIC codes, the mapping unfortunately does not seem satisfactory for industry coverage.

Therefore, we propose an approach that is built on the mapping concept of Kortum and Putnam (1997) and Silverman (2002), but adopts U.S. public firms' patent class distribution. The updated NBER patent database contains Compustat identifiers (GVKEY) that allow us to identify all patents owned by public firms in the Compustat database and then to link patents' technology classes to firms' SIC codes provided in the Compustat database. We first calculate the distribution of firms' SIC codes of each technology class in our sample period 1976-2006. Given $N_{k}$ patents in technology class $k(k=1, \ldots, K)$ owned by U.S. public firms in the sample period, we calculate the percentages of these firms' two-digit SIC codes $(j=1, \ldots, J)$, denoted by $P_{k, 1}, P_{k, 2}, P_{k, 3}, \ldots$, and $P_{k, J}$ (which add up to one). Then, we use these percentages to convert the number of all patents (and citations, originality, and generality) from each sample country by technology classes to the number of the country's patents (and citations, originality, and generality) for each two-digit SIC industry. More specifically, country $i$ 's patent counts in industry $j$ in year $t$ equals $P_{1, j} \times N_{l, i, t}+P_{2, j} \times N_{2, i, t}+\ldots+P_{K, j} \times N_{K, i, t}$, where $N_{k, i, t}$ denotes country $i$ 's patent counts in technology class $k$ in year $t$. This approach is advantageous because it is based on up-to-date U.S. data and is able to connect most technology classes to two-digit SIC codes. Data files containing detailed mapping between USPTO technology classes and two-digit SIC codes are available at the authors' websites.

\section{Appendix B. Constructing shares of total value added and shares of export to the U.S.}

To measure industry $j$ 's share of total value added in manufacturing industries in country $i$ in year $t$, Value-Added ${ }_{j, i, t}$, we first retrieve the data item "Value added" from the Industrial Statistics Database of the United Nations Industrial Development Organization (UNIDO). Since the item "Value added" is based on the International Standard Industrial Classification (ISIC) (Rev3) codes, we use the concordance provided by the United Nations Statistics Division to map ISIC (Rev3) codes to SIC codes for our analyses. ${ }^{15}$

To measure industry $j$ 's share of country $i$ 's total export to the U.S. in year $t$, USExport $_{j, i, t}$, we retrieve the data item "Value" for each sample country's annual export to the U.S. from the website of the United Nations Commodity Trade (UN Comtrade) Statistics Database. However, the UN Comtrade data are based on SITC (Rev3) codes. To solve this issue, we use the concordance lists provided by the United Nations Statistics Division to first convert industrial

\footnotetext{
${ }^{14}$ The details of technology classes can be found at http://www.uspto.gov/web/offices/ac/ido/oeip/taf/cbcby.htm.

15 A complete list of concordances that map ISIC (Rev3) codes to SIC codes is available at http://unstats.un.org/unsd/cr/registry/regdnld.asp? $\mathrm{Lg}=1$.
} 
U.S.-export share from SITC (Rev3) codes to ISIC (Rev3) codes, and then convert these ISIC (Rev3) codes to SIC codes.

\section{Appendix C. Constructing an alternative proxy for high-tech intensiveness}

Griliches (1981), Cockburn and Griliches (1988), and Hall (1993, 2000) propose that firm $i$ 's market value as $V_{i}\left(K_{i}, A_{i}\right)=q_{i}\left(K_{i}+\lambda A_{i}\right)^{\rho}$, in which $K_{i}$ and $A_{i}$ denote firm $i$ 's physical capital and intangible capital, respectively. $\lambda$ measures the shadow value of intangible capital relative to physical capital, and $\rho$ is the parameter governing the return to scale. Both $\lambda$ and $\rho$ are positive. $q_{i}$ is a multiplicative term and is set to be $q_{i}=\exp \left(q^{*}+u_{i}\right)$, in which $q^{*}$ is an average multiplier, and $u_{i}$ denotes a transitory shock with zero mean. Taking natural logarithms of $V_{i}\left(K_{i}\right.$, $A_{i}$ ) gives the following representation: $\ln \left(V_{i}\right)=q^{*}+u_{i}+\rho \ln \left(K_{i}\right)+\rho \ln \left(1+\lambda A_{i} / K_{i}\right) \approx q^{*}+u_{i}+\rho$ $\ln \left(K_{i}\right)+\rho \lambda A_{i} / K_{i}$. Such a logarithmic approximation is appropriate for empirical testing because, for almost all firms, intangible capital measured with accumulated $R \& D$ expenses is relatively smaller when compared to physical capital measured with total assets. By assuming constant return to scale (i.e., $\rho=1$ ) (e.g., Griliches, 1981; Hall, Jaffe, and Trajtenberg, 2005b; Hall, Thoma, and Torrisi, 2007), firm $i$ 's market value-to-assets ratio in logarithm can be represented in a regression format (i.e., $\left.\ln \left(V_{i} / K_{i}\right) \approx q^{*}+u_{i}+\rho \lambda A_{i} / K_{i}\right)$. Also, the above representation can be easily derived from a Cobb-Douglas market value function (see Hall, 2000; Bloom and Van Reenen, 2002). Such a logarithmic approximation suggests a positive relation between a firm's value and its intangible capital. We label $\rho \lambda$ as firm $i$ 's high-tech intensiveness because it governs how firm $i$ 's value responds to its intangible capital. 


\section{References}

Acharya, V.V., Baghai, R., Subramanian, K.V., 2012. Wrongful discharge laws and innovation. Review of Financial Studies, forthcoming.

Acharya, V.V., Subramanian, K.V., 2009. Bankruptcy codes and innovation. Review of Financial Studies 22, 4949-4988.

Aghion, P., Bloom, N., Blundell, R., Griffith, R., Howitt, P., 2005. Competition and innovation: An inverted-U relationship. Quarterly Journal of Economics 120, 701-728.

Aghion, P., Bond, S., Klemm, A., Marinescu, I., 2004. Technology and financial structure: Are innovative firms different? Journal of the European Economic Association 2, 277-288.

Aghion, P., Van Reenen, J., Zingales, L., 2013. Innovation and institutional ownership. American Economic Review 103, 277-304.

Allen, F., Gale, D., 1999. Diversity of opinion and financing of new technologies. Journal of Financial Intermediation 8, 68-89.

Ayyagari, M., Demirgüç-Kunt, A., Maksimovic, V., 2011. Firm innovation in emerging markets: The role of finance, governance, and competition. Journal of Financial and Quantitative Analysis 46, 1545-1580.

Beck, T., Levine, R., 2002. Industry growth and capital allocation: does having a market- or bank-based system matter? Journal of Financial Economics 64, 147-180.

Beck, T., Levine, R., Loayza, N., 2000. Finance and the sources of growth. Journal of Financial Economics 58, 261-300.

Bekaert, G., Harvey, C.R., Lundblad, C., 2005. Does financial liberalization spur growth? Journal of Financial Economics 77, 3-55.

Bencivenga, V.R., Smith, B.D., 1991. Financial intermediation and endogenous growth. Review of Economic Studies 58, 195-209.

Berger, A.N., Udell, G.F., 1990. Collateral, loan quality and bank risk. Journal of Monetary Economics 25, 21-42.

Bernstein, S., 2012. Does going public affect innovation? Unpublished working paper. Stanford University.

Black, S., Strahan, P., 2002. Entrepreneurship and bank credit availability. Journal of Finance 57, 2807-2833.

Bloom, N., Van Reenen, J., 2002. Patents, real options and firm performance. Economic Journal 112, C97-C116.

Bravo-Biosca, A., 2007. Essays on innovation and finance. PhD Thesis. Harvard University.

Brown, J.R., Fazzari, S.M., Petersen, B., 2009. Financing innovation and growth: Cash flow, external equity, and the 1990s R\&D boom. Journal of Finance 64, 151-185.

Brown, J., Martinsson, G., Petersen, B., 2012. Do financing constraints matter for R\&D? European Economic Review, forthcoming.

Cockburn, I., Griliches, Z., 1988. Industry effects and appropriability measures in the stock market's valuation of R\&D and patents. American Economic Review, Papers and Proceedings 78, 419-423.

Djankov, S., McLiesh, C., Shleifer, A., 2007. Private credit in 129 countries. Journal of Financial Economics 84, 299-329.

Fang, V., Tian, X., Tice, S., 2011. Does stock liquidity enhance or impede firm innovation? Unpublished working paper. University of Minnesota.

Ferreira, D., Manso, G., Silva, A. C., 2012. Incentives to innovate and the decision to go public or private. Review of Financial Studies, forthcoming. 
Greenwood, J., Jovanovic, B., 1990. Financial development, growth, and the distribution of income. Journal of Political Economy 98, 1076-1107.

Griffith, R., Harrison, R., Van Reenen, J., 2006. How special is the special relationship? Using the impact of U.S. R\&D spillovers on U.K. firms as a test of technology sourcing. American Economic Review 96, 1859-1875.

Griliches, Z., 1981. Market value, R\&D, and patents. Economics Letters 7, 183-187.

Griliches, Z., Pakes, A., Hall, B.H., 1987. The value of patents as indicators of inventive activity. In: Dasgupta, P., Stoneman, P. (Eds.), Economic Policy and Technical Performance. Cambridge University Press, London, pp. 97-124.

Grossman, S., 1976. On the efficiency of competitive stock markets where trades have diverse information. Journal of Finance 31, 573-585.

Hall, B.H., 1993. The stock market's valuation of R\&D investment during the 1980's. American Economic Review, Papers and Proceedings 83, 259-264.

Hall, B.H., 2000. Innovation and market value. In: Barrell, R., Mason, G., O’Mahoney, M. (Eds.), Productivity, Innovation and Economic Performance. Cambridge University Press, Cambridge, pp.178-198.

Hall, B.H., Jaffe, A.B., Trajtenberg, M., 2005a. The NBER patent citation data file: Lessons, insights and methodological tools. In: Jaffe, A.B., Trajtenberg, M. (Eds.), Patents, Citations and Innovations: A Window on the Knowledge Economy. MIT Press, Cambridge, MA, pp. 403-470.

Hall, B.H., Jaffe, A., Trajtenberg, M., 2005b. Market value and patent citations. RAND Journal of Economics 36, 16-38.

Hall, B.H., Lerner, J, 2010. The financing of R\&D and innovation. In: Hall, B.H., Rosenberg, N. (Eds.), Handbook of the Economics of Innovation. Elsevier, Amsterdam, Netherlands, pp. 610-638.

Hall, B.H., Thoma, G., Torrisi, S., 2007. The market value of patents and R\&D: Evidence from European firms. NBER working paper 13426.

Harhoff, D., Narin, F., Scherer, F.M., Vopel, K., 1999. Citation frequency and the value of patented inventions. Review of Economics and Statistics 81, 511-515.

He, J., Tian, X., 2012. The dark side of analyst coverage: The case of innovation. Journal of Financial Economics, forthcoming.

Hellwig, M., 1991. Banking, financial intermediation, and corporate finance. In: Giovanni, A. (Ed.), European Financial Integration. Cambridge University Press, Cambridge, pp. 35-63.

Holmstrom, B., 1989. Agency costs and innovation. Journal of Economic Behavior and Organization 12, 305-327.

Jappelli, T., Pagano, M, 1993. Savings, growth, and liquidity constraints. Quarterly Journal of Economics 109, 83-109.

Jayaratne, J., Strahan, P., 1996. The finance-growth nexus: Evidence from bank branch deregulation. Quarterly Journal of Economics 111, 639-670.

Kapadia, N., 2006. The next Microsoft? Skewness, idiosyncratic volatility, and expected returns. Unpublished working paper. Rice University.

King, R.G., Levine, R., 1993a. Finance and growth: Schumpeter might be right. Quarterly Journal of Economics 108, 717-737.

King, R.G., Levine, R., 1993b. Finance, entrepreneurship, and growth. Journal of Monetary Economics 32, 513-542. 
Kortum, S.S., Putnam, J., 1997. Assigning patents to industries: Tests of the Yale technology concordance. Economic Systems Research 9, 161-175.

Levine, R., 2005. Finance and growth: Theory and evidence. In: Aghion, P., Durlauf, S. (Eds.), Handbook of Economic Growth, Vol. 1A. Elsevier, Amsterdam, Netherlands, pp. 865-934.

Levine, R., Zervos, S., 1998. Stock markets, banks, and economic growth. American Economic Review 88, 537-558.

Manso, G., 2011. Motivating innovation. Journal of Finance 66, 1823-1860.

Morck, R., Nakamura, M., 1999. Banks and corporate control in Japan. Journal of Finance 54, 319-339.

Nakatani, I., 1984. The role of financial corporate grouping. In: Masahiko A. (Eds.), Economic Analysis of the Japanese Firm. North Holland, New York, pp. 227-258.

Nanda, R., Rhodes-Kropf, M., 2011. Financing risk and innovation. Unpublished working paper. Harvard University.

Nanda, R., Rhodes-Kropf, M., 2012. Investment cycles and startup innovation. Journal of Financial Economics, forthcoming.

Nanda, R., Nicholas, T, 2011. Did bank distress stifle innovation during the Great Depression? Unpublished working paper. Harvard University.

Pástor, L., Veronesi, P., 2009. Technological revolutions and stock prices. American Economic Review 99, 1451-1483.

Petersen, M., 2009. Estimating standard errors in finance panel data sets: Comparing approaches. Review of Financial Studies 22, 435-480.

Rajan, R.G., 1992. Insiders and outsiders: The choice between informed and arm's-length debt. Journal of Finance 47, 1367-1400.

Rajan, R.G., Zingales, L., 1998. Financial dependence and growth. American Economic Review $88,559-586$.

Rajan, R.G., Zingales, L., 2001. Financial systems, industrial structure, and growth. Oxford Review of Economic Policy 17, 467-482.

Robinson, J., 1952. The Rate of Interest and Other Essays. Macmillan, London.

Schmookler, J., 1966. Invention and Economic Growth. Harvard University Press, Cambridge, MA.

Schumpeter, J., 1911. The Theory of Economics Development. Harvard University Press, Cambridge, MA.

Silverman, B.S., 2002. Technological Resources and the Logic of Corporate Diversification. Routledge Press, London.

Solow, R.M., 1957. Technical change and the aggregate production function. Review of Economics and Statistics 39, 312-320.

Stiglitz, J., 1985. Credit markets and capital control. Journal of Money, Credit and Banking 17, 133-152.

Thompson, S., 2011. Simple formulas for standard errors that cluster by both firm and time. Journal of Financial Economics, 99, 1-10.

Tian, X., Wang, T., 2011. Tolerance for failure and corporate innovation. Review of Financial Studies, forthcoming.

Trajtenberg, M., 1990. A penny for your quotes: Patent citations and the value of innovations. RAND Journal of Economics 21, 172-187.

Weinstein, D.E., Yafeh, Y., 1998. On the costs of a bank-centered financial system: Evidence from the changing main bank relations in Japan. Journal of Finance 53, 635-672. 
Table 1

Summary statistics.

This panel reports the country-level averages, including the pooled averages of innovation variables (Patent ${ }^{*}$, Citation ${ }^{*}$, Originality ${ }^{*}$, Generality ${ }^{*}$, and $\left.R \& D^{*}\right)$, Value-Added, and US-Export, and the time-series averages of Equity and Credit. Patent ${ }^{*}$ is defined as the number (in thousands) of patents in industry $j$ filed by non-government institutions or individuals of country $i$ to the USPTO in year $t$. Citation ${ }^{*}$ is defined as the number (in thousands) of patents that cite the patents in industry $j$ filed by non-government institutions or individuals of country $i$ to the USPTO in year $t$. Originality ${ }^{*}$ (Generality ${ }^{*}$ ) is defined as the sum of the originality (generality) scores (in thousands) of patents in industry $j$ filed by non-government institutions or individuals of country $i$ to the USPTO in year $t . R \& D^{*}$ is defined as the sum of all R\&D expenses (in millions of U.S. dollars) reported by public firms in industry $j$ of country $i$ in year $t$. Equity (Credit) is the ratio of stock market capitalization (domestic bank credit) over GDP. Value-Added denotes the share of industry $j$ 's valueadded in country $i$ in year $t$. US-Export denotes the share of industry $j$ 's in country $i$ 's export to the U.S. in year $t$. Industry is defined by two-digit SIC codes. Our sample includes industries with two-digit SIC codes between 20 and 39. The sample period is 1976-2006.

\begin{tabular}{|c|c|c|c|c|c|c|c|c|c|}
\hline Panel A & Patent ${ }^{*}$ & Citation $^{*}$ & $\begin{array}{l}\text { Origi- } \\
\text { nality }^{*}\end{array}$ & $\begin{array}{l}\text { Gene- } \\
\text { rality }\end{array}$ & $R \& D^{*}$ & Equity & Credit & $\begin{array}{l}\text { Value- } \\
\text { Added }\end{array}$ & $\begin{array}{c}U S- \\
\text { Export }\end{array}$ \\
\hline Argentina & 0.002 & 0.021 & 0.000 & 0.000 & 0.000 & 0.273 & 0.369 & 0.050 & 0.047 \\
\hline Australia & 0.033 & 0.297 & 0.004 & 0.003 & 0.008 & 0.821 & 0.705 & 0.047 & 0.044 \\
\hline Austria & 0.029 & 0.189 & 0.002 & 0.002 & 0.007 & 0.183 & 1.102 & 0.050 & 0.049 \\
\hline Belgium & 0.036 & 0.295 & 0.006 & 0.004 & 0.042 & 0.557 & 0.916 & 0.075 & 0.049 \\
\hline Brazil & 0.004 & 0.024 & 0.001 & 0.000 & 0.014 & 0.284 & 0.792 & 0.075 & 0.046 \\
\hline Canada & 0.144 & 1.620 & 0.023 & 0.017 & 0.095 & 0.821 & 1.188 & 0.047 & 0.047 \\
\hline Denmark & 0.020 & 0.158 & 0.002 & 0.002 & 0.029 & 0.470 & 0.796 & 0.047 & 0.045 \\
\hline Finland & 0.029 & 0.269 & 0.005 & 0.003 & 0.129 & 0.853 & 0.627 & 0.048 & 0.047 \\
\hline France & 0.220 & 1.797 & 0.025 & 0.027 & 0.640 & 0.579 & 1.018 & 0.048 & 0.047 \\
\hline Germany & 0.731 & 5.471 & 0.076 & 0.081 & 0.873 & 0.370 & 1.123 & 0.047 & 0.046 \\
\hline Hungary & 0.019 & 0.084 & 0.001 & 0.001 & 0.001 & 0.188 & 0.802 & 0.048 & 0.049 \\
\hline India & 0.013 & 0.053 & 0.002 & 0.000 & 0.007 & 0.341 & 0.477 & 0.045 & 0.043 \\
\hline Ireland & 0.006 & 0.071 & 0.002 & 0.001 & 0.007 & 0.617 & 0.736 & 0.046 & 0.047 \\
\hline Israel & 0.035 & 0.422 & 0.008 & 0.005 & 0.008 & 0.483 & 1.087 & 0.054 & 0.048 \\
\hline Italy & 0.096 & 0.635 & 0.010 & 0.009 & 0.286 & 0.325 & 0.936 & 0.047 & 0.048 \\
\hline Japan & 2.132 & 23.002 & 0.337 & 0.347 & 1.805 & 0.828 & 2.548 & 0.046 & 0.046 \\
\hline Korea & 0.115 & 0.853 & 0.022 & 0.009 & 0.095 & 0.470 & 0.574 & 0.046 & 0.048 \\
\hline Luxembourg & 0.003 & 0.016 & 0.000 & 0.000 & 0.000 & 1.550 & 0.946 & 0.071 & 0.051 \\
\hline Malaysia & 0.002 & 0.017 & 0.001 & 0.000 & 0.002 & 1.624 & 1.125 & 0.045 & 0.046 \\
\hline Mexico & 0.004 & 0.026 & 0.001 & 0.000 & 0.000 & 0.263 & 0.436 & 0.047 & 0.045 \\
\hline Netherlands & 0.072 & 0.641 & 0.011 & 0.010 & 0.190 & 0.921 & 1.267 & 0.048 & 0.044 \\
\hline New Zealand & 0.005 & 0.037 & 0.001 & 0.000 & 0.000 & 0.406 & 0.734 & 0.123 & 0.046 \\
\hline Norway & 0.010 & 0.076 & 0.001 & 0.001 & 0.012 & 0.359 & 0.638 & 0.047 & 0.047 \\
\hline Poland & 0.003 & 0.019 & 0.000 & 0.000 & 0.000 & 0.136 & 0.375 & 0.052 & 0.049 \\
\hline Russia & 0.039 & 0.248 & 0.002 & 0.003 & 0.001 & 0.277 & 0.282 & 0.047 & 0.051 \\
\hline Singapore & 0.011 & 0.131 & 0.004 & 0.002 & 0.004 & 1.611 & 0.635 & 0.047 & 0.047 \\
\hline South Africa & 0.006 & 0.051 & 0.001 & 0.001 & 0.003 & 1.578 & 1.211 & 0.055 & 0.047 \\
\hline Spain & 0.013 & 0.073 & 0.001 & 0.001 & 0.001 & 0.541 & 1.084 & 0.046 & 0.047 \\
\hline Sweden & 0.063 & 0.591 & 0.007 & 0.007 & 0.328 & 0.847 & 0.984 & 0.047 & 0.046 \\
\hline Switzerland & 0.092 & 0.741 & 0.008 & 0.011 & 0.390 & 1.774 & 1.632 & 0.074 & 0.047 \\
\hline U.K. & 0.203 & 1.967 & 0.029 & 0.029 & 0.426 & 1.283 & 0.972 & 0.046 & 0.046 \\
\hline U.S. & 4.167 & 60.604 & 0.958 & 0.745 & 3.579 & 1.093 & 1.635 & 0.046 & - \\
\hline
\end{tabular}




\section{Table 1}

Summary statistics (cont'd).

This panel reports industry-level averages, including the pooled averages of innovation variables (Patent ${ }^{*}$, Citation ${ }^{*}$, Originality $^{*}$, Generality ${ }^{*}$, and $R \& D^{*}$ ), time-series averages of the dependence on external finance (Dependence) and high-tech intensiveness (High-tech), and pooled averages of control variables (Value-Added and US-Export).

\begin{tabular}{|c|c|c|c|c|c|c|c|c|c|c|}
\hline Panel B & Industries & Patent ${ }^{*}$ & Citation $^{*}$ & $\begin{array}{l}\text { Origi- } \\
\text { nality }^{*}\end{array}$ & $\begin{array}{l}\text { Gene- } \\
\text { rality }\end{array}$ & $R \& D^{*}$ & $\begin{array}{l}\text { Depen } \\
\text {-dence }\end{array}$ & $\begin{array}{l}\text { High } \\
\text {-tech }\end{array}$ & $\begin{array}{l}\text { Value- } \\
\text { Added }\end{array}$ & $\begin{array}{c}\text { US- } \\
\text { Export }\end{array}$ \\
\hline 20 & Food and Kindred Products & 0.063 & 0.584 & 0.007 & 0.006 & 0.232 & 1.174 & 1.064 & 0.074 & 0.047 \\
\hline 21 & Tobacco Products & 0.006 & 0.059 & 0.001 & 0.000 & 0.137 & 1.290 & 1.022 & 0.005 & 0.000 \\
\hline 22 & Textile Mill Products & 0.012 & 0.103 & 0.001 & 0.001 & 0.030 & 1.131 & 1.048 & 0.017 & 0.015 \\
\hline 23 & $\begin{array}{l}\text { Apparel and Other Finished Products Made } \\
\text { from Fabrics and Similar Materials }\end{array}$ & 0.006 & 0.053 & 0.000 & 0.000 & 0.014 & 1.474 & 1.188 & 0.052 & 0.057 \\
\hline 24 & Lumber and Wood Products, Except Furniture & 0.010 & 0.102 & 0.001 & 0.001 & 0.016 & 1.177 & 1.109 & 0.028 & 0.011 \\
\hline 25 & Furniture and Fixtures & 0.035 & 0.401 & 0.004 & 0.003 & 0.079 & 1.241 & 1.088 & 0.033 & 0.025 \\
\hline 26 & Paper and Allied Products & 0.173 & 2.084 & 0.033 & 0.027 & 0.077 & 1.104 & 1.018 & 0.039 & 0.021 \\
\hline 27 & Printing, Publishing, and Allied Industries & 0.020 & 0.232 & 0.004 & 0.003 & 0.041 & 1.124 & 1.011 & 0.026 & 0.003 \\
\hline 28 & Chemicals and Allied Products & 1.164 & 10.796 & 0.180 & 0.144 & 2.391 & 1.028 & 1.120 & 0.057 & 0.084 \\
\hline 29 & Petroleum Refining and Related Industries & 0.156 & 1.481 & 0.029 & 0.023 & 0.390 & 1.035 & 0.975 & 0.010 & 0.002 \\
\hline 30 & Rubber and Miscellaneous Plastics Products & 0.080 & 0.804 & 0.013 & 0.011 & 0.193 & 1.203 & 1.029 & 0.047 & 0.035 \\
\hline 31 & Leather and Leather Products & 0.002 & 0.028 & 0.000 & 0.000 & 0.025 & 1.237 & 1.075 & 0.010 & 0.019 \\
\hline 32 & Stone, Clay, Glass, and Concrete Products & 0.087 & 0.897 & 0.016 & 0.013 & 0.074 & 1.102 & 1.062 & 0.025 & 0.013 \\
\hline 33 & Primary Metal Industries & 0.073 & 0.669 & 0.011 & 0.009 & 0.206 & 1.203 & 1.014 & 0.064 & 0.076 \\
\hline 34 & $\begin{array}{l}\text { Fabricated Metal Products, Except Machinery } \\
\text { and Transportation Equipment }\end{array}$ & 0.110 & 1.124 & 0.015 & 0.013 & 0.110 & 1.286 & 1.051 & 0.118 & 0.099 \\
\hline 35 & $\begin{array}{l}\text { Industrial and Commercial Machinery and } \\
\text { Computer Equipment }\end{array}$ & 1.166 & 17.017 & 0.285 & 0.220 & 1.390 & 1.126 & 1.071 & 0.118 & 0.131 \\
\hline 36 & $\begin{array}{l}\text { Electronic and Other Electrical Equipment } \\
\text { and Components, except Computer } \\
\text { Equipment }\end{array}$ & 1.228 & 17.956 & 0.303 & 0.240 & 2.502 & 1.168 & 1.110 & 0.090 & 0.097 \\
\hline 37 & Transportation Equipment & 0.675 & 7.706 & 0.116 & 0.098 & 2.749 & 1.309 & 1.102 & 0.049 & 0.043 \\
\hline 38 & $\begin{array}{l}\text { Measuring, Analyzing, and Controlling } \\
\text { Instruments; Photographic, Medical and } \\
\text { Optical Goods; Watches and Clocks }\end{array}$ & 0.681 & 9.797 & 0.138 & 0.111 & 1.082 & 1.205 & 1.098 & 0.050 & 0.068 \\
\hline 39 & Miscellaneous Manufacturing Industries & 0.057 & 0.735 & 0.005 & 0.005 & 0.086 & 1.304 & 1.085 & 0.065 & 0.072 \\
\hline
\end{tabular}


Table 1

Summary statistics (cont'd).

This panel reports the summary statistics of variables across all country-industry-year observations. Patent, Citation, Originality, Generality, and $R \& D$ are country-industry-year numbers of patents, citation, originality, generality, and R\&D, respectively, scaled by the corresponding industry-year values in U.S. data.

\begin{tabular}{lccccc}
\hline Panel C & Mean & Std. dev. & $25 \%$ & Median & $75 \%$ \\
\hline Patent & 0.057 & 0.184 & 0.001 & 0.004 & 0.021 \\
Citation & 0.050 & 0.178 & 0.001 & 0.003 & 0.015 \\
Originality & 0.049 & 0.179 & 0.000 & 0.002 & 0.012 \\
Generality & 0.054 & 0.186 & 0.000 & 0.002 & 0.014 \\
R\&D & 0.205 & 0.536 & 0.001 & 0.016 & 0.133 \\
Equity & 0.767 & 0.711 & 0.299 & 0.546 & 1.048 \\
Credit & 0.951 & 0.511 & 0.550 & 0.890 & 1.195 \\
Dependence & 1.196 & 0.102 & 1.125 & 1.189 & 1.263 \\
High-tech & 1.067 & 0.047 & 1.026 & 1.068 & 1.100 \\
Value-Added & 0.050 & 0.056 & 0.017 & 0.035 & 0.064 \\
US-Export & 0.047 & 0.063 & 0.007 & 0.023 & 0.064 \\
\hline
\end{tabular}


Table 2

Financial development, dependence on external finance, and innovation.

This table report the results estimating various forms of Innovation $_{j, i, t+1}=\beta_{0}+\beta_{1}$ (Equity $_{i, t} \times$ Dependence $_{j}$ ) $+\beta_{2}\left(\right.$ Credit $_{i, t} \times$ Dependence $\left._{j}\right)+\beta_{3}$ Value-Added $_{j, i, t}+\beta_{4}$ US-Export $_{j, i, t}+\eta_{i, t+1}+\mu_{j}+\varepsilon_{j, i, t+1}$ and Innovation $_{j, i, t+1}=$ $\delta_{0}+\delta_{1}\left(\right.$ Overall $_{i, t} \times$ Dependence $\left._{j}\right)+\delta_{2}$ Value-Added $_{j, i, t}+\delta_{3}$ US-Export $_{j, i, t}+\eta_{i, t+1}+\mu_{j}+\varepsilon_{j, i, t+1}$. Innovation $_{j, i, t+1}$ is the relative innovation measure in industry $j$ in country $i$ in year $t+1$. Relative innovation measures are the count, citation, originality, or generality of non-government patents in year $t+1$ and R\&D in year $t$ scaled by the corresponding values in U.S. data. Equity ${ }_{i, t}$ denotes country $i$ 's stock market capitalization over GDP in year $t$, and Credit $_{i, t}$ denotes country $i$ 's bank credit over GDP in year $t$. Overall ${ }_{i, t}$ denotes country $i$ 's stock market capitalization plus bank credit over GDP in year $t$. Dependence $e_{j}$ denotes two-digit SIC industry $j$ 's dependence on external financing. Value-Added $d_{j, i, t}$ denotes the share of industry $j$ 's value-added in country $i$ in year $t$. US-Export $t_{j, i, t}$ denotes the share of industry $j$ 's in country $i$ 's export to the U.S. in year $t . \eta_{i, t+1}$ denotes the dummies for country $i$ in year $t+1$, while $\mu_{j}$ denotes the dummies for industry $j . \varepsilon_{j, i, t+1}$ denotes the error term. All regressions include a constant term (unreported). The statistical inferences are based on standard errors (reported in parentheses) clustered both by country and by industry. ${ }^{* * *},{ }^{* *}$, and ${ }^{*}$ denote statistical significance at the $1 \%, 5 \%$, and $10 \%$ levels, respectively. Our sample includes industries with two-digit SIC codes between 20 and 39. The sample period is 1976-2006.

\begin{tabular}{|c|c|c|c|c|c|c|c|}
\hline Innovation & $\begin{array}{c}\text { Equity }_{i, t} \\
\times \text { Dependence }_{j}\end{array}$ & $\begin{array}{c}\text { Credit }_{i, t} \\
\times \text { Dependence }_{j}\end{array}$ & $\begin{array}{c}\text { Overall }_{i, t} \\
\times \text { Dependence }_{j}\end{array}$ & $\begin{array}{l}\text { Value- } \\
\text { Added }\end{array}$ & $\begin{array}{c}\text { US- } \\
\text { Export }\end{array}$ & $\begin{array}{c}\text { Adj- } \\
R^{2}\end{array}$ & Obs. \\
\hline Patent (1) & $\begin{array}{l}0.013^{* *} \\
(0.006)\end{array}$ & & & $\begin{array}{c}0.005 \\
(0.013)\end{array}$ & $\begin{array}{l}0.061^{* *} \\
(0.025)\end{array}$ & 0.829 & 7548 \\
\hline Patent (2) & & $\begin{array}{l}-0.115^{* *} \\
(0.058)\end{array}$ & & $\begin{array}{c}0.006 \\
(0.013)\end{array}$ & $\begin{array}{l}0.053^{* *} \\
(0.024)\end{array}$ & 0.835 & 7434 \\
\hline Patent (3) & $\begin{array}{c}0.047^{* * *} \\
(0.018)\end{array}$ & $\begin{array}{l}-0.128^{* *} \\
(0.062)\end{array}$ & & $\begin{array}{c}0.006 \\
(0.013)\end{array}$ & $\begin{array}{l}0.055^{* *} \\
(0.024)\end{array}$ & 0.836 & 7354 \\
\hline Patent (4) & & & $\begin{array}{l}-0.037 \\
(0.024)\end{array}$ & $\begin{array}{c}0.004 \\
(0.013)\end{array}$ & $\begin{array}{l}0.058^{* *} \\
(0.025)\end{array}$ & 0.831 & 7354 \\
\hline Citation (5) & $\begin{array}{l}0.012^{* *} \\
(0.005)\end{array}$ & & & $\begin{array}{c}0.009 \\
(0.009)\end{array}$ & $\begin{array}{l}0.032^{* * *} \\
(0.012)\end{array}$ & 0.763 & 7548 \\
\hline Citation (6) & & $\begin{array}{l}-0.077^{* *} \\
(0.033)\end{array}$ & & $\begin{array}{c}0.010 \\
(0.009)\end{array}$ & $\begin{array}{l}0.026^{* *} \\
(0.012)\end{array}$ & 0.767 & 7434 \\
\hline Citation (7) & $\begin{array}{l}0.033^{* * *} \\
(0.010)\end{array}$ & $\begin{array}{l}-0.087^{* *} \\
(0.035)\end{array}$ & & $\begin{array}{c}0.011 \\
(0.010)\end{array}$ & $\begin{array}{l}0.028^{* *} \\
(0.012)\end{array}$ & 0.767 & 7354 \\
\hline Citation (8) & & & $\begin{array}{l}-0.023 \\
(0.015)\end{array}$ & $\begin{array}{c}0.009 \\
(0.009)\end{array}$ & $\begin{array}{l}0.030^{* *} \\
(0.012)\end{array}$ & 0.764 & 7354 \\
\hline Originality (9) & $\begin{array}{l}0.011^{* *} \\
(0.004)\end{array}$ & & & $\begin{array}{c}0.011 \\
(0.008)\end{array}$ & $\begin{array}{l}0.035^{* * *} \\
(0.013)\end{array}$ & 0.773 & 7548 \\
\hline Originality (10) & & $\begin{array}{l}-0.051^{*} \\
(0.026)\end{array}$ & & $\begin{array}{c}0.012 \\
(0.008)\end{array}$ & $\begin{array}{l}0.031^{* *} \\
(0.013)\end{array}$ & 0.775 & 7434 \\
\hline Originality (11) & $\begin{array}{l}0.026^{* * *} \\
(0.009)\end{array}$ & $\begin{array}{l}-0.059^{* *} \\
(0.028)\end{array}$ & & $\begin{array}{c}0.012 \\
(0.009)\end{array}$ & $\begin{array}{l}0.033^{* *} \\
(0.013)\end{array}$ & 0.775 & 7354 \\
\hline Originality (12) & & & $\begin{array}{l}-0.014 \\
(0.012)\end{array}$ & $\begin{array}{c}0.011 \\
(0.008)\end{array}$ & $\begin{array}{l}0.034^{* * *} \\
(0.013)\end{array}$ & 0.773 & 7354 \\
\hline Generality (13) & $\begin{array}{l}0.008^{*} \\
(0.004)\end{array}$ & & & $\begin{array}{c}0.010 \\
(0.009)\end{array}$ & $\begin{array}{l}0.041^{* * *} \\
(0.015)\end{array}$ & 0.801 & 6814 \\
\hline Generality (14) & & $\begin{array}{l}-0.066 \\
(0.042)\end{array}$ & & $\begin{array}{c}0.010 \\
(0.009)\end{array}$ & $\begin{array}{l}0.037^{* * *} \\
(0.014)\end{array}$ & 0.804 & 6700 \\
\hline Generality (15) & $\begin{array}{l}0.025^{* *} \\
(0.011)\end{array}$ & $\begin{array}{l}-0.073 \\
(0.044)\end{array}$ & & $\begin{array}{c}0.010 \\
(0.010)\end{array}$ & $\begin{array}{l}0.039^{* * *} \\
(0.015)\end{array}$ & 0.804 & 6620 \\
\hline
\end{tabular}




\begin{tabular}{|c|c|c|c|c|c|c|c|}
\hline Generality (16) & & & $\begin{array}{l}-0.021 \\
(0.017)\end{array}$ & $\begin{array}{c}0.009 \\
(0.009)\end{array}$ & $\begin{array}{c}0.041^{* * *} \\
(0.015)\end{array}$ & 0.802 & 6620 \\
\hline$R \& D(17)$ & $\begin{array}{c}0.714 \\
(0.500)\end{array}$ & & & $\begin{array}{c}42.019 \\
(45.099)\end{array}$ & $\begin{array}{c}28.678 \\
(34.888)\end{array}$ & 0.236 & 3582 \\
\hline$R \& D(18)$ & & $\begin{array}{l}-0.877 \\
(1.235)\end{array}$ & & $\begin{array}{c}48.965 \\
(43.328)\end{array}$ & $\begin{array}{c}15.954 \\
(36.702)\end{array}$ & 0.238 & 3561 \\
\hline$R \& D(19)$ & $\begin{array}{c}0.943 \\
(0.606)\end{array}$ & $\begin{array}{l}-1.008 \\
(1.286)\end{array}$ & & $\begin{array}{c}45.516 \\
(44.846)\end{array}$ & $\begin{array}{c}20.709 \\
(37.820)\end{array}$ & 0.239 & 3536 \\
\hline$R \& D(20)$ & & & $\begin{array}{c}-0.216 \\
(0.638)\end{array}$ & $\begin{array}{c}45.361 \\
(43.899)\end{array}$ & $\begin{array}{c}20.340 \\
(36.719)\end{array}$ & 0.236 & 3536 \\
\hline
\end{tabular}


Table 3

Financial development, high-tech intensiveness, and innovation.

This table reports the results estimating various forms of Innovation $_{j, i, t+1}=\beta_{0}+\beta_{1}$ (Equity $_{i, t} \times$ High-tech $_{j}$ ) $+\beta_{2}\left(\right.$ Credit $_{i, t} \times$ High-tech $\left._{j}\right)+\beta_{3}$ Value-Added $_{j, i, t}+\beta_{4}$ US-Export $_{j, i, t}+\eta_{i, t+1}+\mu_{j}+\varepsilon_{j, i, t+1}$ and Innovation $_{j, i, t+1}=\delta_{0}$ $+\delta_{1}\left(\right.$ Overall $_{i, t} \times$ High-tech $\left._{j}\right)+\delta_{2}$ Value-Added $_{j, i, t}+\delta_{3} U S$-Export Hi,it $_{j}+\eta_{i, t+1}+\mu_{j}+\varepsilon_{j, i, t+1}$. Innovation Ini,t+l $_{j}$ is the relative innovation measure in industry $j$ in country $i$ in year $t+1$. Relative innovation measures are the count, citation, originality, or generality of non-government patents in year $t+1$ and $\mathrm{R} \& \mathrm{D}$ in year $t$ scaled by the corresponding values in U.S. data. Equity ${ }_{i, t}$ denotes country $i$ 's stock market capitalization over GDP in year $t$, and Credit $_{i, t}$ denotes country $i$ 's bank credit over GDP in year $t$. Overall $l_{i, t}$ denotes country $i$ 's stock market

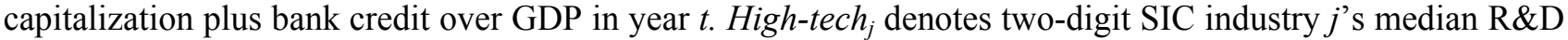
growth in the U.S. Value-Added $d_{j, i, t}$ denotes the share of industry $j$ 's value-added in country $i$ in year $t$. USExport $_{j, i, t}$ denotes the share of industry $j$ 's in country $i$ 's export to the U.S. in year $t . \eta_{i, t+1}$ denotes the dummies for country $i$ in year $t+1$, while $\mu_{j}$ denotes the dummies for industry $j . \varepsilon_{j, i, t+1}$ denotes the error term. All regressions include a constant term (unreported). The statistical inferences are based on standard errors (reported in parentheses) clustered both by country and by industry. ${ }^{* * *},{ }^{* *}$, and ${ }^{*}$ denote statistical significance at the 1\%,5\%, and 10\% levels, respectively. Our sample includes industries with two-digit SIC codes between 20 and 39. The sample period is 1976-2006.

\begin{tabular}{|c|c|c|c|c|c|c|c|}
\hline Innovation & $\begin{array}{l}\text { Equity }_{i, t} \times \\
\text { High-tech }_{j}\end{array}$ & $\begin{array}{l}\text { Credit }_{i, t} \times \\
\text { High-tech }_{j}\end{array}$ & $\begin{array}{l}\text { Overall }_{i, t} \times \\
\text { High-tech }_{j}\end{array}$ & $\begin{array}{l}\text { Value- } \\
\text { Added }\end{array}$ & $\begin{array}{c}\text { US- } \\
\text { Export }\end{array}$ & $\begin{array}{c}\text { Adj- } \\
R^{2}\end{array}$ & Obs. \\
\hline Patent (1) & $\begin{array}{c}0.014^{* * *} \\
(0.005)\end{array}$ & & & $\begin{array}{c}0.003 \\
(0.003)\end{array}$ & $\begin{array}{l}0.022^{* * *} \\
(0.004)\end{array}$ & 0.918 & 7548 \\
\hline Patent (2) & & $\begin{array}{c}-0.085^{* * *} \\
(0.016)\end{array}$ & & $\begin{array}{c}0.002 \\
(0.003)\end{array}$ & $\begin{array}{c}0.025^{* * * *} \\
(0.004)\end{array}$ & 0.920 & 7434 \\
\hline Patent (3) & $\begin{array}{c}0.038^{* * *} \\
(0.007)\end{array}$ & $\begin{array}{c}-0.096^{* * *} \\
(0.016)\end{array}$ & & $\begin{array}{c}0.003 \\
(0.003)\end{array}$ & $\begin{array}{l}0.025^{* * * *} \\
(0.004)\end{array}$ & 0.920 & 7354 \\
\hline Patent (4) & & & $\begin{array}{c}-0.026^{* * *} \\
(0.008)\end{array}$ & $\begin{array}{c}0.002 \\
(0.003)\end{array}$ & $\begin{array}{c}0.025^{* * *} \\
(0.004)\end{array}$ & 0.919 & 7354 \\
\hline Citation (5) & $\begin{array}{c}0.014^{* * *} \\
(0.004)\end{array}$ & & & $\begin{array}{l}0.005^{*} \\
(0.003)\end{array}$ & $\begin{array}{l}0.013^{* * * *} \\
(0.005)\end{array}$ & 0.870 & 7548 \\
\hline Citation (6) & & $\begin{array}{c}-0.055^{* * *} \\
(0.016)\end{array}$ & & $\begin{array}{c}0.005 \\
(0.003)\end{array}$ & $\begin{array}{c}0.015^{* * *} \\
(0.005)\end{array}$ & 0.874 & 7434 \\
\hline Citation (7) & $\begin{array}{c}0.030^{* * *} \\
(0.006)\end{array}$ & $\begin{array}{c}-0.063^{* * *} \\
(0.017)\end{array}$ & & $\begin{array}{l}0.005^{*} \\
(0.003)\end{array}$ & $\begin{array}{l}0.015^{* * *} \\
(0.005)\end{array}$ & 0.874 & 7354 \\
\hline Citation (8) & & & $\begin{array}{c}-0.015^{* *} \\
(0.007)\end{array}$ & $\begin{array}{c}0.004 \\
(0.003)\end{array}$ & $\begin{array}{l}0.015^{* * *} \\
(0.005)\end{array}$ & 0.873 & 7354 \\
\hline Originality (9) & $\begin{array}{c}0.011^{* * *} \\
(0.004)\end{array}$ & & & $\begin{array}{l}0.005^{*} \\
(0.003)\end{array}$ & $\begin{array}{l}0.014^{* * *} \\
(0.005)\end{array}$ & 0.872 & 7548 \\
\hline Originality (10) & & $\begin{array}{l}-0.021^{*} \\
(0.012)\end{array}$ & & $\begin{array}{c}0.004 \\
(0.003)\end{array}$ & $\begin{array}{l}0.015^{* * *} \\
(0.005)\end{array}$ & 0.873 & 7434 \\
\hline Originality (11) & $\begin{array}{c}0.018^{* * *} \\
(0.005)\end{array}$ & $\begin{array}{l}-0.026^{* *} \\
(0.013)\end{array}$ & & $\begin{array}{c}0.005 \\
(0.003)\end{array}$ & $\begin{array}{c}0.016^{* * *} \\
(0.006)\end{array}$ & 0.873 & 7354 \\
\hline Originality (12) & & & $\begin{array}{l}-0.003 \\
(0.005)\end{array}$ & $\begin{array}{c}0.004 \\
(0.003)\end{array}$ & $\begin{array}{l}0.016^{* * *} \\
(0.006)\end{array}$ & 0.873 & 7354 \\
\hline Generality (13) & $\begin{array}{l}0.010^{* *} \\
(0.005)\end{array}$ & & & $\begin{array}{c}0.004 \\
(0.003)\end{array}$ & $\begin{array}{l}0.016^{* * *} \\
(0.006)\end{array}$ & 0.882 & 6814 \\
\hline Generality (14) & & $\begin{array}{c}-0.059^{* * *} \\
(0.018)\end{array}$ & & $\begin{array}{c}0.003 \\
(0.003)\end{array}$ & $\begin{array}{c}0.018^{* * *} \\
(0.006)\end{array}$ & 0.885 & 6700 \\
\hline Generality (15) & $\begin{array}{c}0.028^{* * *} \\
(0.007)\end{array}$ & $\begin{array}{c}-0.067^{* * *} \\
(0.020)\end{array}$ & & $\begin{array}{c}0.004 \\
(0.003)\end{array}$ & $\begin{array}{l}0.019^{* * * *} \\
(0.006)\end{array}$ & 0.885 & 6620 \\
\hline
\end{tabular}




\begin{tabular}{|c|c|c|c|c|c|c|c|}
\hline Generality (16) & & & $\begin{array}{c}-0.018^{* *} \\
(0.008)\end{array}$ & $\begin{array}{c}0.003 \\
(0.003)\end{array}$ & $\begin{array}{c}0.019^{* * *} \\
(0.006)\end{array}$ & 0.884 & 6620 \\
\hline$R \& D(17)$ & $\begin{array}{l}1.848^{* *} \\
(0.862)\end{array}$ & & & $\begin{array}{l}3.833^{* * * *} \\
(1.052)\end{array}$ & $\begin{array}{l}3.062^{* * *} \\
(1.210)\end{array}$ & 0.695 & 3582 \\
\hline$R \& D(18)$ & & $\begin{array}{l}-0.661 \\
(2.157)\end{array}$ & & $\begin{array}{l}3.759^{* * * *} \\
(1.045)\end{array}$ & $\begin{array}{l}3.387^{* * *} \\
(1.282)\end{array}$ & 0.695 & 3561 \\
\hline$R \& D(19)$ & $\begin{array}{l}2.166^{* *} \\
(0.908)\end{array}$ & $\begin{array}{l}-1.279 \\
(2.243)\end{array}$ & & $\begin{array}{l}3.892^{* * * *} \\
(1.077)\end{array}$ & $\begin{array}{l}3.361^{* * * *} \\
(1.291)\end{array}$ & 0.695 & 3536 \\
\hline$R \& D(20)$ & & & $\begin{array}{c}0.503 \\
(1.030)\end{array}$ & $\begin{array}{l}3.863^{* * *} \\
(1.077)\end{array}$ & $\begin{array}{l}3.359^{* * * *} \\
(1.292)\end{array}$ & 0.695 & 3536 \\
\hline
\end{tabular}




\section{Table 4}

Robustness checks - country-industry fixed effects.

This table reports the robustness check results with country-industry fixed effects controlled. We estimate Innovation $_{j, i, t+1}=\beta_{0}+\beta_{1}\left(\right.$ Equity $_{i, t} \times$ Industry $\left._{j}\right)+\beta_{2}\left(\right.$ Credit $_{i, t} \times$ Industry $\left._{j}\right)+\beta_{3}$ Value-Added $_{j, i, t}+\beta_{4}$ USExport $_{j, i, t}+\eta_{j, i}+\varepsilon_{j, i, t+1}$. Innovation $_{j, i, t+1}$ is the relative innovation measures in industry $j$ in country $i$ in year $t+1$. Relative innovation measures are the count, citation, originality, or generality of non-government patents in year $t+1$ and R\&D in year $t$ scaled by the corresponding values in U.S. data. Equity $y_{i, t}$ denotes country $i$ 's stock market capitalization over GDP in year $t$, and Credit $t_{i, t}$ denotes country $i$ 's bank credit over GDP in year $t$.

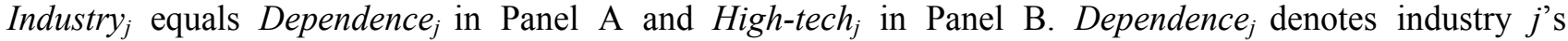
dependence on external financing, and High-tech ${ }_{j}$ denotes industry $j$ 's median R\&D growth in the U.S. ValueAdded $_{j, i, t}$ denotes the share of industry $j$ 's value-added in country $i$ in year $t$. US-Export $t_{j, i, t}$ denotes the share of industry $j$ 's in country $i$ 's export to the U.S. in year $t . \eta_{j, i}$ denotes the dummies for industry $j$ in country $i . \varepsilon_{j, i, t+1}$ denotes the error term. All regressions include a constant term (unreported). The statistical inferences are based on standard errors (reported in parentheses) clustered both by country and by industry. ${ }^{* * *},{ }^{* *}$, and ${ }^{*}$ denote statistical significance at the $1 \%, 5 \%$, and $10 \%$ levels, respectively. Our sample includes industries with two-digit SIC codes between 20 and 39. The sample period is 1976-2006.

\begin{tabular}{|c|c|c|c|c|c|c|}
\hline $\begin{array}{l}\text { Panel A } \\
\text { Innovation }\end{array}$ & $\begin{array}{c}\quad \text { Equity }_{i, t} \\
\times \text { Dependence }_{j} \\
\end{array}$ & $\begin{array}{c}\text { Credit }_{i, t} \\
\times \text { Dependence }_{j}\end{array}$ & $\begin{array}{l}\text { Value- } \\
\text { Added }\end{array}$ & $\begin{array}{c}U S- \\
\text { Export }\end{array}$ & $\begin{array}{c}\text { Adj- } \\
R^{2}\end{array}$ & Obs. \\
\hline Patent & $\begin{array}{l}0.006^{* * *} \\
(0.001)\end{array}$ & $\begin{array}{c}-0.004^{* * *} \\
(0.001)\end{array}$ & $\begin{array}{l}-0.003 \\
(0.009)\end{array}$ & $\begin{array}{l}-0.014 \\
(0.016)\end{array}$ & 0.892 & 7354 \\
\hline Citation & $\begin{array}{l}0.005^{* * *} \\
(0.001)\end{array}$ & $\begin{array}{c}-0.011^{* * *} \\
(0.002)\end{array}$ & $\begin{array}{c}0.002 \\
(0.010)\end{array}$ & $\begin{array}{l}-0.021 \\
(0.023)\end{array}$ & 0.653 & 7354 \\
\hline Originality & $\begin{array}{l}0.004^{* * *} \\
(0.001)\end{array}$ & $\begin{array}{c}-0.006^{* * *} \\
(0.002)\end{array}$ & $\begin{array}{l}-0.007 \\
(0.012)\end{array}$ & $\begin{array}{l}-0.025 \\
(0.027)\end{array}$ & 0.563 & 7354 \\
\hline Generality & $\begin{array}{l}0.007^{* * *} \\
(0.001)\end{array}$ & $\begin{array}{c}-0.006^{* * *} \\
(0.002)\end{array}$ & $\begin{array}{c}0.002 \\
(0.011)\end{array}$ & $\begin{array}{l}-0.028 \\
(0.029)\end{array}$ & 0.744 & 6620 \\
\hline$R \& D$ & $\begin{array}{l}0.063^{* *} \\
(0.027)\end{array}$ & $\begin{array}{l}-0.100^{*} \\
(0.053) \\
\end{array}$ & $\begin{array}{c}10.254 \\
(14.360) \\
\end{array}$ & $\begin{array}{c}-1.579 \\
(61.731) \\
\end{array}$ & 0.637 & 3536 \\
\hline $\begin{array}{l}\text { Panel B } \\
\text { Innovation }\end{array}$ & $\begin{array}{l}\text { Equity }_{i, t} \times \\
\text { High-tech }_{j}\end{array}$ & $\begin{array}{l}\text { Credit }_{i, t} \times \\
\text { High-tech }_{j}\end{array}$ & $\begin{array}{l}\text { Value- } \\
\text { Added }\end{array}$ & $\begin{array}{c}\text { US- } \\
\text { Export }\end{array}$ & $\begin{array}{l}\text { Adj- } \\
R^{2}\end{array}$ & Obs. \\
\hline Patent & $\begin{array}{l}0.005^{* * *} \\
(0.001)\end{array}$ & $\begin{array}{c}-0.004^{* * *} \\
(0.001)\end{array}$ & $\begin{array}{l}-0.005 \\
(0.007)\end{array}$ & $\begin{array}{l}-0.005 \\
(0.014)\end{array}$ & 0.886 & 7354 \\
\hline Citation & $\begin{array}{l}0.003^{* * *} \\
(0.001)\end{array}$ & $\begin{array}{c}-0.010^{* * *} \\
(0.002)\end{array}$ & $\begin{array}{l}-0.013 \\
(0.009)\end{array}$ & $\begin{array}{l}-0.012 \\
(0.024)\end{array}$ & 0.639 & 7354 \\
\hline Originality & $\begin{array}{l}0.004^{* * * *} \\
(0.001)\end{array}$ & $\begin{array}{c}-0.010^{* * *} \\
(0.002)\end{array}$ & $\begin{array}{l}-0.013 \\
(0.009)\end{array}$ & $\begin{array}{l}-0.015 \\
(0.024)\end{array}$ & 0.621 & 7354 \\
\hline Generality & $\begin{array}{l}0.002^{* * *} \\
(0.001)\end{array}$ & $\begin{array}{c}-0.012^{* * *} \\
(0.003)\end{array}$ & $\begin{array}{c}0.000 \\
(0.007)\end{array}$ & $\begin{array}{l}-0.014 \\
(0.022)\end{array}$ & 0.667 & 6620 \\
\hline$R \& D$ & $\begin{array}{c}0.143 \\
(0.076)\end{array}$ & $\begin{array}{c}0.885 \\
(0.541) \\
\end{array}$ & $\begin{array}{c}0.313 \\
(0.824) \\
\end{array}$ & $\begin{array}{l}-4.324 \\
(5.781) \\
\end{array}$ & 0.886 & 3536 \\
\hline
\end{tabular}




\section{Table 5}

Robustness checks - clustering standard errors by country.

This table reports the robustness check results with standard errors of coefficient estimates clustered by country. We estimate Innovation $_{j, i, t+1}=\beta_{0}+\beta_{1}\left(\right.$ Equity $_{i, t} \times$ Industry $\left._{j}\right)+\beta_{2}\left(\right.$ Credit $_{i, t} \times$ Industry $\left._{j}\right)+\beta_{3}$ ValueAdded $_{j, i, t}+\beta_{4}$ US-Export $_{j, i, t}+\eta_{i, t+1}+\mu_{j}+\varepsilon_{j, i, t+1}$. Innovation $_{j, i, t+1}$ is the relative innovation measures in industry $j$ in country $i$ in year $t+1$. Relative innovation measures are the count, citation, originality, or generality of nongovernment patents in year $t+1$ and R\&D in year $t$ scaled by the corresponding values in U.S. data. Equity $y_{i, t}$ denotes country $i$ 's stock market capitalization over GDP in year $t$, and Credit $t_{i, t}$ denotes country $i$ 's bank credit over GDP in year $t$. Industry I $_{j}$ equals Dependence ${ }_{j}$ in Panel A and High-tech $h_{j}$ in Panel B. Dependence $e_{j}$ denotes industry $j$ 's dependence on external financing, and High-tech $h_{j}$ denotes industry $j$ 's median R\&D growth in the U.S. Value-Added ${ }_{j, i, t}$ denotes the share of industry $j$ 's value-added in country $i$ in year $t$. USExport $_{j, i, t}$ denotes the share of industry $j$ 's in country $i$ 's export to the U.S. in year $t . \eta_{i, t+1}$ denotes the dummies for country $i$ in year $t+1$, while $\mu_{j}$ denotes the dummies for industry $j . \varepsilon_{j, i, t+1}$ denotes the error term. All regressions include a constant term (unreported). The statistical inferences are based on standard errors (reported in parentheses) clustered by country. ${ }^{* * *},{ }^{* *}$, and ${ }^{*}$ denote statistical significance at the $1 \%, 5 \%$, and $10 \%$ levels, respectively. Our sample includes industries with two-digit SIC codes between 20 and 39. The sample period is 1976-2006.

\begin{tabular}{|c|c|c|c|c|c|c|}
\hline $\begin{array}{l}\text { Panel A } \\
\text { Innovation }\end{array}$ & $\begin{array}{c}\quad \text { Equity }_{i, t} \\
\times \text { Dependence }_{j}\end{array}$ & $\begin{array}{c}\text { Credit }_{i, t} \\
\times \text { Dependence }_{j}\end{array}$ & $\begin{array}{l}\text { Value- } \\
\text { Added }\end{array}$ & $\begin{array}{c}\text { US- } \\
\text { Export }\end{array}$ & $\begin{array}{c}\text { Adj- } \\
R^{2}\end{array}$ & Obs. \\
\hline Patent & $\begin{array}{l}0.047^{* *} \\
(0.022)\end{array}$ & $\begin{array}{c}-0.128^{* * *} \\
(0.045)\end{array}$ & $\begin{array}{c}0.006 \\
(0.011)\end{array}$ & $\begin{array}{c}0.055 \\
(0.043)\end{array}$ & 0.836 & 7354 \\
\hline Citation & $\begin{array}{l}0.033^{* *} \\
(0.015)\end{array}$ & $\begin{array}{l}-0.087^{* *} \\
(0.039)\end{array}$ & $\begin{array}{l}0.011 \\
(0.010)\end{array}$ & $\begin{array}{c}0.028 \\
(0.018)\end{array}$ & 0.767 & 7354 \\
\hline Originality & $\begin{array}{l}0.026^{* *} \\
(0.012)\end{array}$ & $\begin{array}{l}-0.059^{* * *} \\
(0.028)\end{array}$ & $\begin{array}{c}0.012 \\
(0.011)\end{array}$ & $\begin{array}{c}0.033 \\
(0.021)\end{array}$ & 0.775 & 7354 \\
\hline Generality & $\begin{array}{l}0.025^{* *} \\
(0.011)\end{array}$ & $\begin{array}{c}-0.073^{* * *} \\
(0.023)\end{array}$ & $\begin{array}{c}0.010 \\
(0.012)\end{array}$ & $\begin{array}{c}0.039 \\
(0.025)\end{array}$ & 0.804 & 6620 \\
\hline$R \& D$ & $\begin{array}{c}0.943^{*} \\
(0.514)\end{array}$ & $\begin{array}{l}-1.008^{*} \\
(0.498)\end{array}$ & $\begin{array}{r}45.516 \\
(45.993)\end{array}$ & $\begin{array}{c}20.709 \\
(52.176) \\
\end{array}$ & 0.239 & 3536 \\
\hline $\begin{array}{l}\text { Panel B } \\
\text { Innovation }\end{array}$ & $\begin{array}{l}\text { Equity }_{i, t} \times \\
\text { High-tech }_{j}\end{array}$ & $\begin{array}{l}\text { Credit }_{i, t} \times \\
\text { High-tech }_{j}\end{array}$ & $\begin{array}{l}\text { Value- } \\
\text { Added }\end{array}$ & $\begin{array}{c}U S- \\
\text { Export }\end{array}$ & $\begin{array}{l}\text { Adj- } \\
R^{2}\end{array}$ & Obs. \\
\hline Patent & $\begin{array}{l}0.038^{* *} \\
(0.018)\end{array}$ & $\begin{array}{c}-0.096^{* * *} \\
(0.024)\end{array}$ & $\begin{array}{c}0.003 \\
(0.006)\end{array}$ & $\begin{array}{l}0.025^{* *} \\
(0.012)\end{array}$ & 0.920 & 7354 \\
\hline Citation & $\begin{array}{l}0.030^{* *} \\
(0.011)\end{array}$ & $\begin{array}{c}-0.063^{* * *} \\
(0.020)\end{array}$ & $\begin{array}{c}0.005 \\
(0.005)\end{array}$ & $\begin{array}{l}0.015^{* *} \\
(0.007)\end{array}$ & 0.874 & 7354 \\
\hline Originality & $\begin{array}{l}0.018^{* * * *} \\
(0.006)\end{array}$ & $\begin{array}{l}-0.026^{* *} \\
(0.010)\end{array}$ & $\begin{array}{l}0.005 \\
(0.004)\end{array}$ & $\begin{array}{l}0.016^{* *} \\
(0.006)\end{array}$ & 0.873 & 7354 \\
\hline Generality & $\begin{array}{l}0.028^{* *} \\
(0.011)\end{array}$ & $\begin{array}{c}-0.067^{* * *} \\
(0.017)\end{array}$ & $\begin{array}{c}0.004 \\
(0.005)\end{array}$ & $\begin{array}{l}0.019^{* *} \\
(0.007)\end{array}$ & 0.885 & 6620 \\
\hline$R \& D$ & $\begin{array}{c}2.166 \\
(1.416)\end{array}$ & $\begin{array}{l}-1.279 \\
(1.394)\end{array}$ & $\begin{array}{c}3.892 \\
(2.752)\end{array}$ & $\begin{array}{c}3.361 \\
(3.685)\end{array}$ & 0.695 & 3536 \\
\hline
\end{tabular}




\section{Table 6}

Robustness checks - alternative proxies for financial development.

This table reports the robustness check results using alternative proxies for financial development. We estimate Innovation $_{j, i, t+1}=\beta_{0}+\beta_{1}\left(\right.$ Equity $_{i, t} \times$ Industry $\left._{j}\right)+\beta_{2}\left(\right.$ Credit $_{i, t} \times$ Industry $\left._{j}\right)+\beta_{3}$ Value-Added $_{j, i, t}+\beta_{4}$ $U S$-Export $t_{j, i, t}+\eta_{i, t+1}+\mu_{j}+\varepsilon_{j, i, t+1}$. Innovation $_{j, i, t+1}$ is the relative innovation measures in industry $j$ in country $i$ in year $t+1$. Relative innovation measures are the count, citation, originality, or generality of non-government patents in year $t+1$ and R\&D in year $t$ scaled by the corresponding values in U.S. data. Equity denotes $^{-1}$ country $i$ 's stock market traded value over GDP in year $t$, and Credit $t_{i, t}$ denotes country $i$ 's private credit over GDP in year $t$. Industry ${ }_{j}$ equals Dependence $_{j}$ in Panel A and High-tech ${ }_{j}$ in Panel B. Dependence ${ }_{j}$ denotes industry $j$ 's dependence on external financing, and High-tech $h_{j}$ denotes industry $j$ 's median R\&D growth in the U.S. Value-Added $d_{j, i, t}$ denotes the share of industry $j$ 's value-added in country $i$ in year $t$. US-Export $t_{j, i, t}$ denotes the share of industry $j$ 's in country $i$ 's export to the U.S. in year $t . \eta_{i, t+1}$ denotes the dummies for country $i$ in year $t+1$, while $\mu_{j}$ denotes the dummies for industry $j . \varepsilon_{j, i, t+1}$ denotes the error term. All regressions include a constant term (unreported). The statistical inferences are based on standard errors (reported in parentheses) clustered both by country and by industry. ${ }^{* * *},{ }^{* *}$, and ${ }^{*}$ denote statistical significance at the $1 \%, 5 \%$, and $10 \%$ levels, respectively. Our sample includes industries with two-digit SIC codes between 20 and 39. The sample period is 1976-2006.

\begin{tabular}{|c|c|c|c|c|c|c|}
\hline $\begin{array}{l}\text { Panel A } \\
\text { Innovation }\end{array}$ & $\begin{array}{c}\text { Equity }_{i, t} \\
\times \text { Dependence }_{j}\end{array}$ & $\begin{array}{c}\text { Credit }_{i, t} \\
\times \text { Dependence }_{j}\end{array}$ & $\begin{array}{l}\text { Value- } \\
\text { Added }\end{array}$ & $\begin{array}{c}\text { US- } \\
\text { Export }\end{array}$ & $\begin{array}{c}\text { Adj- } \\
R^{2}\end{array}$ & Obs. \\
\hline Patent & $\begin{array}{c}0.057^{* * *} \\
(0.015)\end{array}$ & $\begin{array}{c}-0.132^{* * *} \\
(0.027)\end{array}$ & $\begin{array}{c}0.005 \\
(0.007)\end{array}$ & $\begin{array}{l}0.055^{* * *} \\
(0.012)\end{array}$ & 0.834 & 7354 \\
\hline Citation & $\begin{array}{l}0.026^{* *} \\
(0.013)\end{array}$ & $\begin{array}{c}-0.074^{* * * *} \\
(0.028)\end{array}$ & $\begin{array}{l}0.009^{*} \\
(0.005)\end{array}$ & $\begin{array}{l}0.028^{* *} \\
(0.011)\end{array}$ & 0.765 & 7354 \\
\hline Originality & $\begin{array}{c}0.014 \\
(0.010)\end{array}$ & $\begin{array}{l}-0.045^{*} \\
(0.023)\end{array}$ & $\begin{array}{l}0.011^{*} \\
(0.006)\end{array}$ & $\begin{array}{l}0.033^{* * * *} \\
(0.012)\end{array}$ & 0.774 & 7354 \\
\hline Generality & $\begin{array}{c}0.008 \\
(0.012)\end{array}$ & $\begin{array}{l}-0.057^{* *} \\
(0.029)\end{array}$ & $\begin{array}{c}0.009 \\
(0.007)\end{array}$ & $\begin{array}{l}0.040^{* * *} \\
(0.013)\end{array}$ & 0.803 & 6620 \\
\hline$R \& D$ & $\begin{array}{c}0.000 \\
(0.843)\end{array}$ & $\begin{array}{l}-1.004 \\
(1.565)\end{array}$ & $\begin{array}{c}47.535 \\
(43.459) \\
\end{array}$ & $\begin{array}{c}16.295 \\
(37.142) \\
\end{array}$ & 0.237 & 3536 \\
\hline $\begin{array}{l}\text { Panel B } \\
\text { Innovation }\end{array}$ & $\begin{array}{l}\text { Equity }_{i, t} \times \\
\text { High-tech }_{j}\end{array}$ & $\begin{array}{l}\text { Credit }_{i, t} \times \\
\text { High-tech }_{j}\end{array}$ & $\begin{array}{l}\text { Value- } \\
\text { Added }\end{array}$ & $\begin{array}{c}\text { US- } \\
\text { Export }\end{array}$ & $\begin{array}{l}\text { Adj- } \\
R^{2}\end{array}$ & Obs. \\
\hline Patent & $\begin{array}{l}0.033^{* * *} \\
(0.010)\end{array}$ & $\begin{array}{c}-0.094^{* * *} \\
(0.020)\end{array}$ & $\begin{array}{c}0.002 \\
(0.003)\end{array}$ & $\begin{array}{l}0.025^{* * *} \\
(0.004)\end{array}$ & 0.920 & 7354 \\
\hline Citation & $\begin{array}{l}0.024^{* *} \\
(0.010)\end{array}$ & $\begin{array}{c}-0.058^{* * *} \\
(0.020)\end{array}$ & $\begin{array}{c}0.004 \\
(0.003)\end{array}$ & $\begin{array}{l}0.016^{* * *} \\
(0.006)\end{array}$ & 0.873 & 7354 \\
\hline Originality & $\begin{array}{c}0.003 \\
(0.007)\end{array}$ & $\begin{array}{l}-0.014 \\
(0.014)\end{array}$ & $\begin{array}{c}0.004 \\
(0.003)\end{array}$ & $\begin{array}{l}0.016^{* * *} \\
(0.006)\end{array}$ & 0.873 & 7354 \\
\hline Generality & $\begin{array}{c}0.017^{*} \\
(0.010)\end{array}$ & $\begin{array}{c}-0.062^{* * *} \\
(0.019)\end{array}$ & $\begin{array}{c}0.003 \\
(0.003)\end{array}$ & $\begin{array}{l}0.019^{* * * *} \\
(0.006)\end{array}$ & 0.885 & 6620 \\
\hline$R \& D$ & $\begin{array}{l}-0.873 \\
(3.002) \\
\end{array}$ & $\begin{array}{c}0.105 \\
(2.612)\end{array}$ & $\begin{array}{l}3.781^{* * * *} \\
(1.064)\end{array}$ & $\begin{array}{l}3.482^{* * *} \\
(1.315)\end{array}$ & 0.695 & 3536 \\
\hline
\end{tabular}




\section{Table 7}

Financial development, an alternative proxy for high-tech intensiveness, and innovation.

This table reports the robustness check results using an alternative proxy for an industry's high-tech intensiveness. We estimate Innovation $_{j, i, t+1}=\beta_{0}+\beta_{1}\left(\right.$ Equity $_{i, t} \times$ High-tech $\left._{j}\right)+\beta_{2}\left(\right.$ Credit $_{i, t} \times$ High-tech $\left._{j}\right)+\beta_{3}$ Value-Added $_{j, i, t}+\beta_{4}$ US-Export $_{j, i, t}+\eta_{i, t+1}+\mu_{j}+\varepsilon_{j, i, t+1}$. Innovation $_{j, i, t+1}$ is the relative innovation measure in industry $j$ in country $i$ in year $t+1$. Relative innovation measures are the count, citation, originality, or generality of non-government patents in year $t+1$ and $\mathrm{R} \& \mathrm{D}$ in year $t$ scaled by the corresponding values in U.S. data. Equity ${ }_{i, t}$ denotes country $i$ 's stock market capitalization over GDP in year $t$, and Credit $_{i, t}$ denotes country $i$ 's bank credit over GDP in year $t$. High-tech $h_{j}$ denotes two-digit SIC industry $j$ 's median coefficient from regressing logarithmic ratio of market value to total assets on five-year R\&D expenses scaled by total assets. Value-Added ${ }_{j, i, t}$ denotes the share of industry $j$ 's value-added in country $i$ in year $t$. US-Export $t_{j, i, t}$ denotes the share of industry $j$ 's in country $i$ 's export to the U.S. in year $t . \eta_{i, t+1}$ denotes the dummies for country $i$ in year $t+1$, while $\mu_{j}$ denotes the dummies for industry $j . \varepsilon_{j, i, t+1}$ denotes the error term. All regressions include a constant term (unreported). The statistical inferences are based on standard errors (reported in parentheses) clustered both by country and by industry. ${ }^{* * *},{ }^{* *}$, and ${ }^{*}$ denote statistical significance at the $1 \%, 5 \%$, and $10 \%$ levels, respectively. Our sample includes industries with two-digit SIC codes between 20 and 39. The sample period is 1976-2006.

\begin{tabular}{lcccccc}
\hline Innovation & $\begin{array}{c}\text { Equity }_{i, t} \times \\
\text { High-tech }_{j}\end{array}$ & $\begin{array}{c}\text { Credit }_{i, t} \times \\
\text { High-tech }_{j}\end{array}$ & $\begin{array}{c}\text { Value- } \\
\text { Added }\end{array}$ & $\begin{array}{c}\text { US- } \\
\text { Export }\end{array}$ & $\begin{array}{c}\text { Adj- } \\
R^{2}\end{array}$ & Obs. \\
\hline Patent & $0.011^{* *}$ & $-0.017^{*}$ & 0.007 & $0.062^{* *}$ & 0.838 & 7354 \\
& $(0.005)$ & $(0.009)$ & $(0.013)$ & $(0.024)$ & & \\
Citation & $0.003^{* *}$ & $-0.005^{* * *}$ & -0.004 & 0.026 & 0.774 & 7354 \\
& $(0.002)$ & $(0.002)$ & $(0.007)$ & $(0.023)$ & & \\
Originality & $0.006^{*}$ & $-0.008^{*}$ & 0.002 & $0.029^{* *}$ & 0.788 & 7354 \\
& $(0.003)$ & $(0.004)$ & $(0.008)$ & $(0.014)$ & & \\
Generality & $0.002^{* *}$ & $-0.003^{* * *}$ & -0.003 & 0.039 & 0.817 & 6620 \\
\multirow{2}{*}{ R\&D } & $(0.001)$ & $(0.001)$ & $(0.008)$ & $(0.033)$ & & \\
& -0.043 & 0.013 & -0.430 & -0.265 & 0.154 & 3536 \\
& $(0.110)$ & $(0.149)$ & $(0.415)$ & $(0.354)$ & & \\
\hline
\end{tabular}




\section{Table 8}

Robustness checks - technology class analysis.

This table reports the robustness check results using innovation proxies defined at the technology class level. We estimate Innovation $_{j, i, t+1}=\beta_{0}+\beta_{1}\left(\right.$ Equity $_{i, t} \times$ Industry $\left._{j}\right)+\beta_{2}\left(\right.$ Credit $_{i, t} \times$ Industry $\left._{j}\right)+\beta_{3}$ ValueAdded $_{j, i, t}+\beta_{4}$ US-Export $_{j, i, t}+\eta_{i, t+1}+\mu_{j}+\varepsilon_{j, i, t+1}$. Innovation $_{j, i, t+1}$ is the relative innovation measure in technology class $j$ in country $i$ in year $t+1$. Relative innovation measures are the count, citation, originality, or generality of non-government patents in year $t+1$ and $\mathrm{R} \& \mathrm{D}$ in year $t$ scaled by the corresponding values in U.S. data.

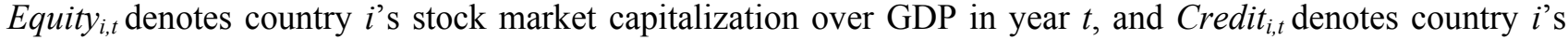

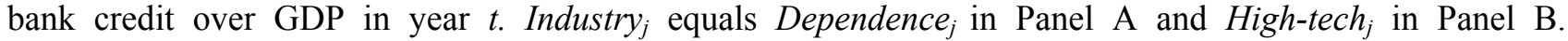
Dependence $_{j}$ denotes technology class $j$ 's dependence on external financing, and High-tech ${ }_{j}$ denotes

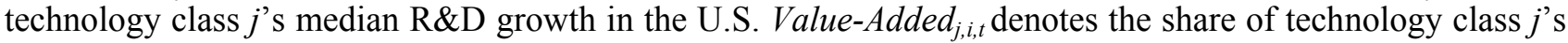
value-added in country $i$ in year $t$. US-Export $t_{j, i, t}$ denotes the share of technology class $j$ 's in country $i$ 's export to the U.S. in year $t . \eta_{i, t+1}$ denotes the dummies for country $i$ in year $t+1$, while $\mu_{j}$ denotes the dummies for technology class $j . \varepsilon_{j, i, t+1}$ denotes the error term. All regressions include a constant term (unreported). The statistical inferences are based on standard errors (reported in parentheses) clustered by technology class and by country. ${ }^{* * *},{ }^{* *}$, and ${ }^{*}$ denote statistical significance at the $1 \%, 5 \%$, and $10 \%$ levels, respectively. The sample period is 1976-2006.

\begin{tabular}{|c|c|c|c|c|c|c|}
\hline $\begin{array}{l}\text { Panel A } \\
\text { Innovation }\end{array}$ & $\begin{array}{c}\text { Equity }_{i, t} \\
\times \text { Dependence }_{j}\end{array}$ & $\begin{array}{c}\text { Credit }_{i, t} \\
\times \text { Dependence }_{j}\end{array}$ & $\begin{array}{l}\text { Value- } \\
\text { Added }\end{array}$ & $\begin{array}{c}\text { US- } \\
\text { Export }\end{array}$ & $\begin{array}{c}\text { Adj- } \\
R^{2}\end{array}$ & Obs. \\
\hline Patent & $\begin{array}{c}0.059^{* * *} \\
(0.018)\end{array}$ & $\begin{array}{c}-0.089^{* * *} \\
(0.030)\end{array}$ & $\begin{array}{l}-0.446 \\
(0.367)\end{array}$ & $\begin{array}{c}1.525 \\
(1.121)\end{array}$ & 0.166 & 63620 \\
\hline Citation & $\begin{array}{l}0.030^{* * * *} \\
(0.011)\end{array}$ & $\begin{array}{c}-0.037^{* * *} \\
(0.013)\end{array}$ & $\begin{array}{l}-0.382 \\
(0.315)\end{array}$ & $\begin{array}{c}1.272 \\
(1.021)\end{array}$ & 0.141 & 62138 \\
\hline Originality & $\begin{array}{l}0.042^{* *} \\
(0.016)\end{array}$ & $\begin{array}{c}-0.044^{* * *} \\
(0.011)\end{array}$ & $\begin{array}{l}-0.393 \\
(0.339)\end{array}$ & $\begin{array}{l}1.467 \\
(1.075)\end{array}$ & 0.167 & 52628 \\
\hline Generality & $\begin{array}{c}0.005 \\
(0.021)\end{array}$ & $\begin{array}{l}-0.033^{*} \\
(0.019)\end{array}$ & $\begin{array}{l}-0.565 \\
(0.421)\end{array}$ & $\begin{array}{l}1.848 \\
(1.294)\end{array}$ & 0.159 & 34812 \\
\hline$R \& D$ & $\begin{array}{c}0.005 \\
(0.004) \\
\end{array}$ & $\begin{array}{c}0.003 \\
(0.007) \\
\end{array}$ & $\begin{array}{l}-1.979 \\
(1.366) \\
\end{array}$ & $\begin{array}{c}5.696 \\
(3.807) \\
\end{array}$ & 0.414 & 62497 \\
\hline $\begin{array}{l}\text { Panel B } \\
\text { Innovation }\end{array}$ & $\begin{array}{l}\text { Equity }_{i, t} \times \\
\text { High-tech }_{j}\end{array}$ & $\begin{array}{l}\text { Credit }_{i, t} \times \\
\text { High-tech }_{j}\end{array}$ & $\begin{array}{l}\text { Value- } \\
\text { Added }\end{array}$ & $\begin{array}{c}\text { US- } \\
\text { Export }\end{array}$ & $\begin{array}{l}\text { Adj- } \\
R^{2}\end{array}$ & Obs. \\
\hline Patent & $\begin{array}{l}0.622^{* *} \\
(0.294)\end{array}$ & $\begin{array}{c}-1.988^{* * * *} \\
(0.474)\end{array}$ & $\begin{array}{l}-0.387 \\
(0.308)\end{array}$ & $\begin{array}{l}1.287 \\
(0.906)\end{array}$ & 0.167 & 63620 \\
\hline Citation & $\begin{array}{l}0.796^{* *} \\
(0.395)\end{array}$ & $\begin{array}{c}-2.386^{* * *} \\
(0.691)\end{array}$ & $\begin{array}{l}-0.291 \\
(0.231)\end{array}$ & $\begin{array}{c}0.970 \\
(0.730)\end{array}$ & 0.142 & 62138 \\
\hline Originality & $\begin{array}{l}0.477^{*} \\
(0.255)\end{array}$ & $\begin{array}{c}-1.679^{* * *} \\
(0.456)\end{array}$ & $\begin{array}{l}-0.339 \\
(0.272)\end{array}$ & $\begin{array}{l}1.228 \\
(0.841)\end{array}$ & 0.168 & 52628 \\
\hline Generality & $\begin{array}{c}0.389 \\
(0.270)\end{array}$ & $\begin{array}{c}-1.528^{* * *} \\
(0.381)\end{array}$ & $\begin{array}{l}-0.481 \\
(0.335)\end{array}$ & $\begin{array}{c}1.519 \\
(0.988)\end{array}$ & 0.160 & 34812 \\
\hline$R \& D$ & $\begin{array}{c}36.570^{*} \\
(18.686)\end{array}$ & $\begin{array}{l}-91.687^{* *} \\
(42.162)\end{array}$ & $\begin{array}{l}-37.772 \\
(36.234)\end{array}$ & $\begin{array}{c}142.206 \\
(106.300)\end{array}$ & 0.414 & 62497 \\
\hline
\end{tabular}

